I NTER NATIONAL MONETARY FUND
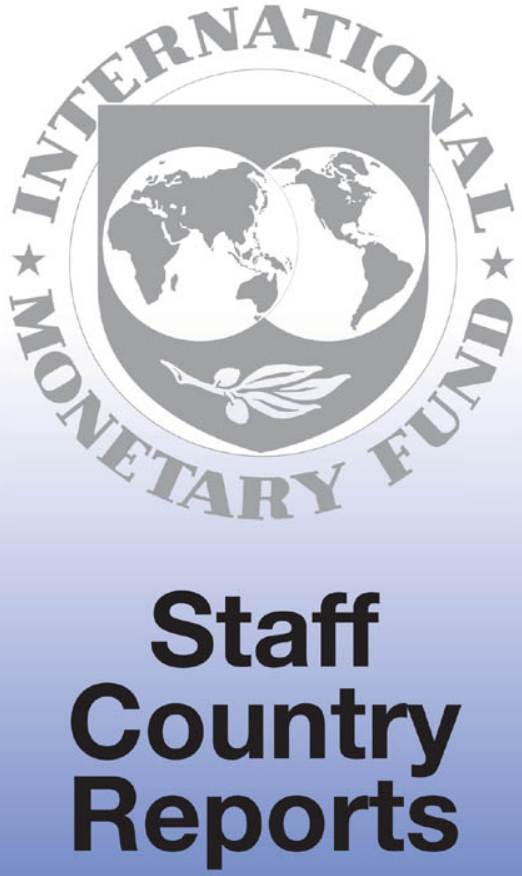


\section{Samoa: 2010 Article IV Consultation-Staff Report; Joint World Bank/IMF Debt Sustainability Analysis; Public Information Notice on the Executive Board Discussion; and Statement by the Executive Director for Samoa}

Under Article IV of the IMF's Articles of Agreement, the IMF holds bilateral discussions with members, usually every year. In the context of the 2010 Article IV consultation with Samoa, the following documents have been released and are included in this package:

- $\quad$ The staff report for the 2010 Article IV consultation, prepared by a staff team of the IMF, following discussions that ended on March 6, 2010, with the officials of Samoa on economic developments and policies. Based on information available at the time of these discussions, the staff report was completed on April 22, 2010. The views expressed in the staff report are those of the staff team and do not necessarily reflect the views of the Executive Board of the IMF.

- $\quad$ A staff supplement consisting of the joint World Bank/IMF debt sustainability analysis.

- $\quad$ A Public Information Notice (PIN) summarizing the views of the Executive Board as expressed during its May 17, 2010 discussion of the staff report that concluded the Article IV consultation.

- $\quad$ A statement by the Executive Director for Samoa.

The document listed below has been or will be separately released.

\section{Selected Issues Paper}

The policy of publication of staff reports and other documents allows for the deletion of market-sensitive information.

Copies of this report are available to the public from

International Monetary Fund • Publication Services

$70019^{\text {th }}$ Street, N.W. • Washington, D.C. 20431

Telephone: (202) 623-7430 • Telefax: (202) 623-7201

E-mail: publications@imf.org Internet: http://www.imf.org

\section{International Monetary Fund Washington, D.C.}


This page intentionally left blank

CInternational Monetary Fund. Not for Redistribution 
INTERNATIONAL MONETARY FUND

\author{
SAMOA
}

\title{
Staff Report for the 2010 Article IV Consultation
}

Prepared by the Staff Representatives for the 2010 Consultation with Samoa

Approved by Ray Brooks and Aasim Husain

April 22, 2010

Context: Samoa has been subject to severe social and economic shocks. The September 2009 tsunami undercut prospects for a quick recovery from the global recession and saddled Samoa with massive private and public sector rebuilding costs. The Fund has played a catalytic role in securing donor support and provided emergency assistance under the ESF/RAC of SDR5.8 million (50 percent of quota).

Discussions: Apia, March 2-6, 2010 with Prime Minister Tuilaepa Malielegaoi, Ministry of Finance Chief Executive Iulai Lavea, Central Bank of Samoa Governor Papali'I Tommy Scanlan, and other senior officials and representatives from financial and business sectors as well as donors.

Team: Mr. Unteroberdoerster (head), Ms. Pongsaparn (all APD), Mr. Ralyea (FIN), and Mr. Mellor (AsDB). Mr. Pereira (OED) participated in the discussions.

Focus: Disaster rehabilitation and economic recovery; fiscal sustainability; private-sector led growth.

Exchange Rate: Samoa maintains a peg to a basket of currencies with undisclosed weights. Samoa has accepted the obligations of Article VIII, Sections 2, 3, and 4, and maintains an exchange system that is free of restrictions on payments and transfers for current international transactions.

Previous Fund Advice: Samoa has a good track record in maintaining fiscal sustainability and pursuing structural reform in line with Fund recommendations. The authorities remain committed to measures outlined in the staff report for the ESF/RAC request (IMF Country Report No. 10/46) that would underpin macroeconomic stability during tsunami-related reconstruction.

Statistical Issues: Core economic data are updated regularly and published on official websites. National accounts data are not prepared on an expenditure basis, while balance of payments data are limited and subject to frequent revisions.

Consultation Cycle: 24-month. The authorities would welcome an interim staff visit. 


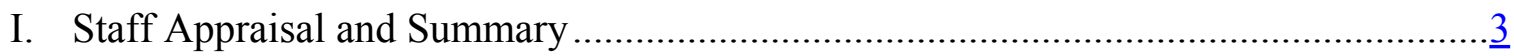

II. Background: Weathering the Global Recession and 2009 Tsunami ............................ 4

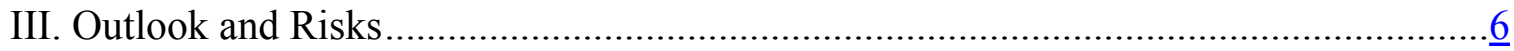

IV. Policy Discussions: Returning to Sustained Growth ............................................... 1

A. Fiscal Management: From Rebuilding to Maintaining Sustainability …………….. $\underline{8}$

B. Monetary and Exchange Rate Policy: Managing a Sound Framework .................... 9

C. Structural Reform: Promoting Private-Sector Led Growth ...................................10

Boxes

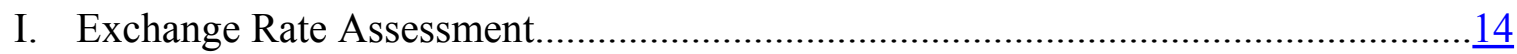

II. Tapping the Economic Potential of Customary Land.............................................15

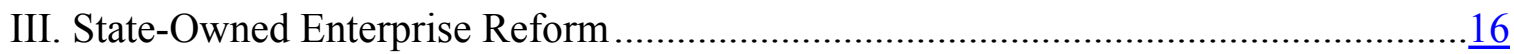

Figures

1. Samoa and Its Peers During the Global Recession................................................. 5

2. Selected Exchange Rate and Financial Indicators ....................................................11

Tables

1. Selected Economic and Financial Indicators, 2004/05-2010/11 …..........................17

2. Illustrative Medium-Term Baseline Scenario, 2005/06-2013/14 ...............................18

3. Balance of Payments, 2004/05-2010/11 ……….................................................

4. Financial Operations of the Central Government, 2005/06-2010/11 ….....................20

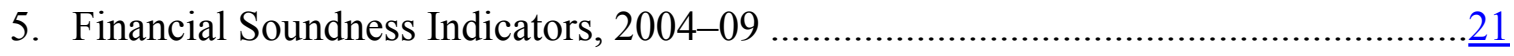




\section{StafF ApPraisal AND SUMmary}

1. Samoa has suffered severe social and economic shocks. The September 2009 tsunami undercut prospects for a quick recovery from the global recession and saddled Samoa with massive private and public sector rebuilding costs. The authorities responded swiftly, adopted a fully-costed rehabilitation plan, and made quick progress in securing concessional financing. The Fund has played a catalytic role in securing donor support and provided emergency assistance under the ESF/RAC of SDR5.8 million (50 percent of quota).

2. The outlook is challenging and subject to considerable uncertainty. Because of the tsunami's potentially severe impact on tourism, real GDP is likely to contract this financial year while faltering export earnings and reconstruction-related imports could result in a significant widening of the current account deficit. The unprecedented scale of the disaster, a still fragile global recovery, and weaknesses in Samoa's national accounts data mean that the timing and strength of the eventual recovery are difficult to predict. Moreover, Samoa remains exposed to severe natural disaster risks.

\section{The fiscal strategy to shoulder the rebuilding costs, minimize capacity risks, and} ensure fiscal sustainability remains appropriate. In line with commitments supporting the authorities' request for emergency financial assistance (IMF Country Report No. 10/46), Samoa has made significant progress in securing concessional donor support and prioritizing reconstruction spending. However, further efforts along these lines will be needed to address the remaining tsunami-related fiscal financing gap. Moreover, it will be important to return to the public deficit target once reconstruction is completed to safeguard Samoa's favorable debt outlook and fiscal space to deal with future shocks. Effective and timely implementation of the government's public financial management reform plan will help underpin this strategy.

\section{Prudent management of monetary policy and the basket peg will be more critical}

than usual. In spite of severe shocks, the basket peg has remained credible, while the tala exchange rate does not appear out of line with economic fundamentals. However, in order to avoid undue fiscal tightening during the reconstruction period, the Central Bank of Samoa (CBS) will need to be vigilant in detecting early signs of balance of payment pressures and should make adjustments if necessary. While the current historically low policy rates are appropriate, the CBS should in time adopt a more neutral stance as the domestic recovery gains traction and regional central banks withdraw stimulus.

\section{Eventually, the Samoan economy will need to rely more on a vibrant private} sector for growth. The staff welcomes the authorities' commitment to wide-ranging structural reform. In particular, efforts to increase access to and economic use of customary land, and state-owned enterprise reform will be important to attract more private investment (both foreign and domestic) and improve overall economic efficiency. 


\section{BACKGROUND: WEATHERING THE GLOBAL RECESSION AND 2009 TSUNAMI}

\section{After more than a decade of strong economic performance, the global recession} and the 2009 tsunami dealt Samoa major setbacks (Table 1 and Figure 1).

- $\quad$ Real per-capita income growth since the mid-1990s has been significantly higher than for most comparator countries. Prudent fiscal and monetary policies and structural reforms underpinned this performance.

- However, the global recession hit parts of the economy severely, notably manufacturing with the downsizing of a plant for automotive parts. In addition, construction also recorded a significant decline in FY 2008/09, in part reflecting the unwinding of activity related to the South Pacific Games, while agriculture and fishing suffered from poor harvests. As a result, real GDP fell 5 percent in FY 2008/09, recording the worst slump in two decades. Estimates for the first quarter of FY 2009/10 point to continued economic weakness with GDP recording a further decline of 2.3 percent $(\mathrm{y} / \mathrm{y})$.

- Nevertheless, Samoa's external position remained comfortable. The current account deficit narrowed in FY 2008/09 (on provisional data) as remittances and tourism receipts, Samoa's main foreign exchange earners, continued to grow. Official reserves remained stable, well above the central bank's target.

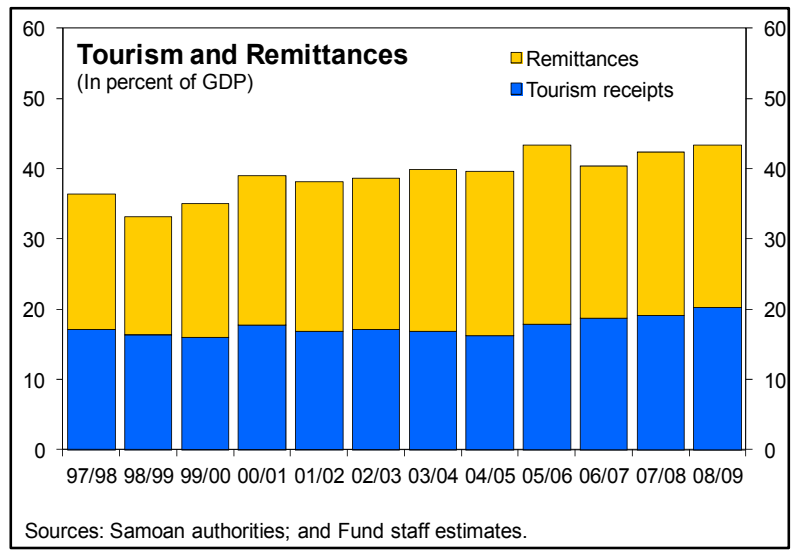

- $\quad$ The tsunami in September 2009 caused human suffering and damage to physical infrastructure, including tourism, of an unprecedented scale. Beyond the human cost, the physical damage is estimated by the UNDP and the World Bank at US\$60 million (over 10 percent of GDP), but the cost of infrastructure rehabilitation, strengthening social safety nets, and investing in disaster protection, including resettlement, is expected to be significantly higher.

7. The government responded swiftly to both shocks, supported by foreign aid and Samoan communities.

- $\quad$ The authorities responded early in the global recession with monetary and fiscal stimulus. The Central Bank of Samoa (CBS) has lowered policy rates (CBS securities overall rate) by nearly 500bps since mid 2008 to $1 / 4$ percent, broadly in line with Australia and New Zealand. However, the pass-through to commercial lending rates has been limited as banks tightened risk management and built excess liquidity. As part of an economic stimulus package in the wake of the global recession, the 
Figure 1: Samoa and Its Peers During the Global Recession

Despite strong macroeconomic performance over the last two decades,...

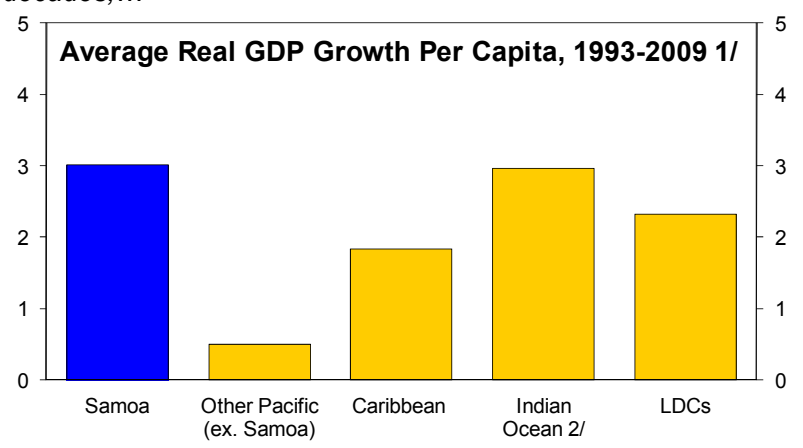

Sources: IMF, World Economic Outlook database; and Fund staff calculations. 1/ Simple averages.

2/ Mauritius, Seychelles and Maldives.

However, thanks to resilient tourism receipts and remittances, the current account balance improved...

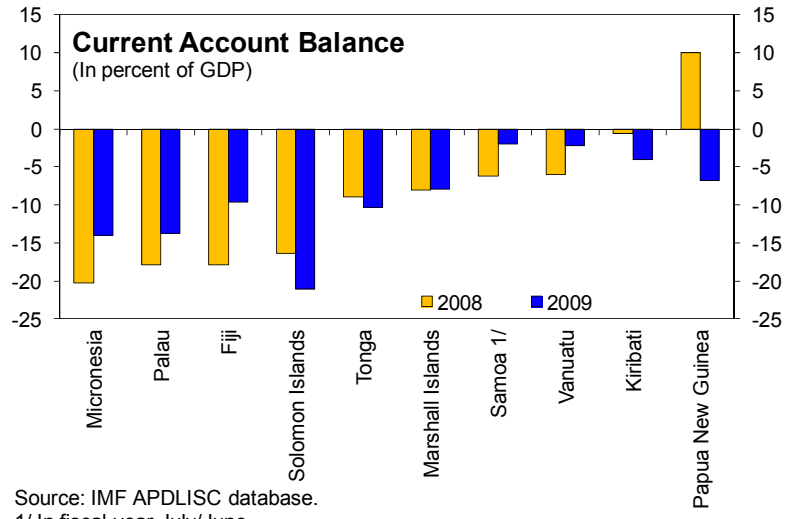

$1 /$ In fiscal year July/June.

Moreover, with the 2008/09 budget, the authorities shifted to an expansionary fiscal stance, mainly through an increase in development spending...

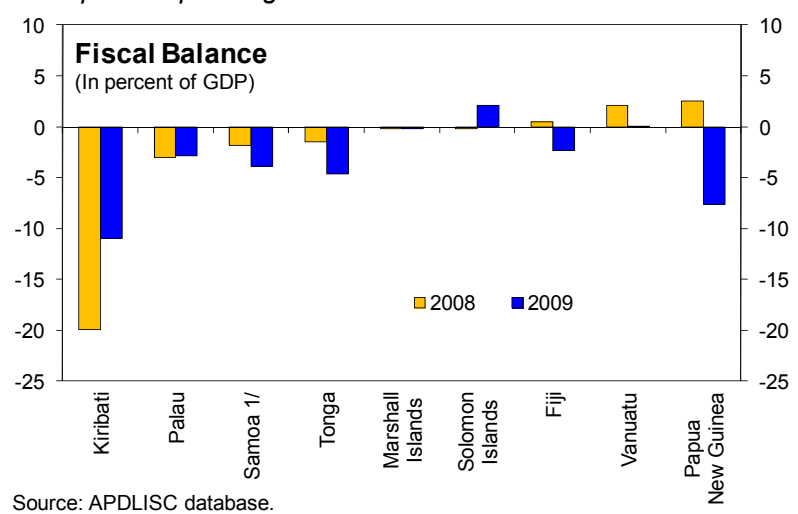

Sourcis APDLISC database.
...Samoa was not immune to the global recession.

Manufacturing output and processing trade collapsed.

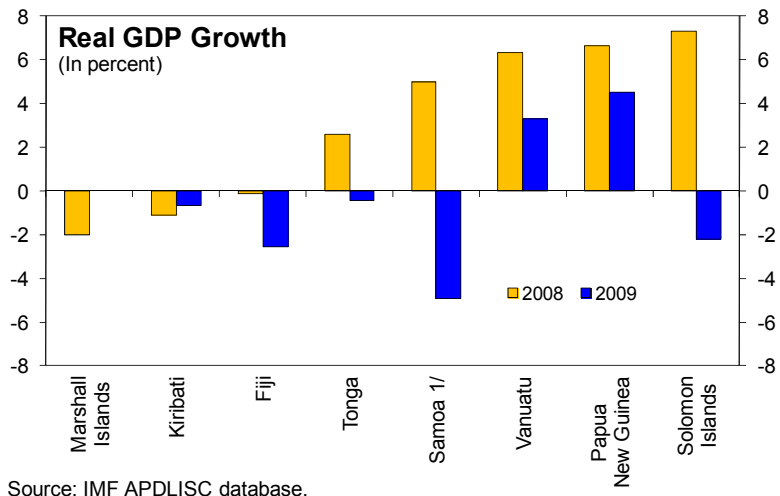

$1 /$ In fiscal year July/June.

... and official reserves remained stable around the central bank's target (of 4 months of import cover).

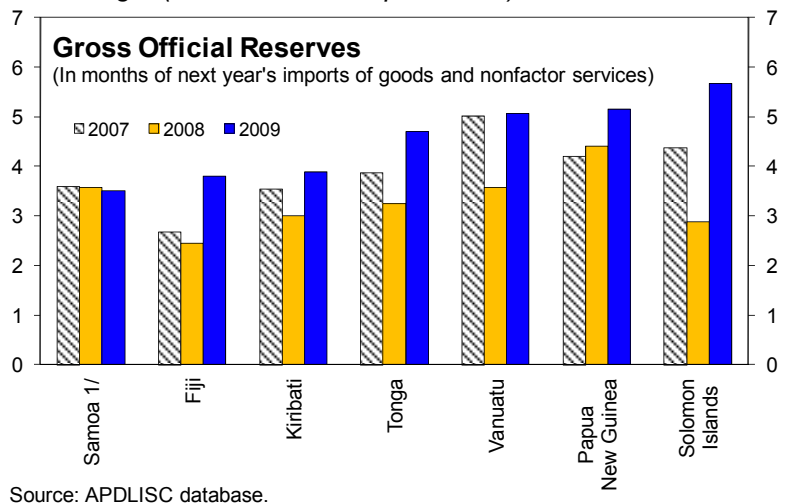

$1 /$ In fiscal year July/June.

...while seeking concessional external financing to keep public debt within sustainable thresholds.

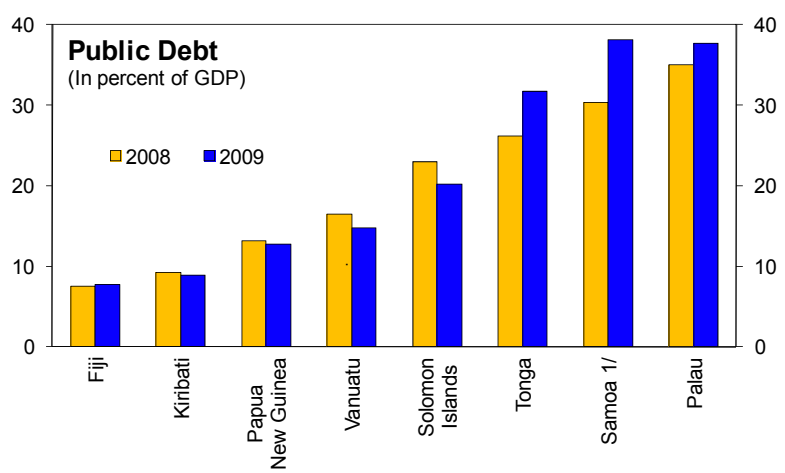

Source: IMF APDLISC database.

$1 /$ In fiscal year July/June. Total external public debt. 
government started to increase development spending in 2008. The deficit was budgeted to double to over 10 percent of GDP in FY 2009/10, largely financed by grants and concessional loans.

- A massive humanitarian relief effort was mounted within days after the 2009 tsunami and attention is now shifting toward implementing a recovery framework that focuses on maintaining access to basic health and education services, infrastructure rehabilitation, resettlement, and investments in disaster risk reduction. Given the poverty implications of the disaster, the framework is integrated with the Strategy for the Development of Samoa (SDS) 2008-12, Samoa's blue-print for poverty reduction and growth.

- A strong initial response from private overseas remittances and donor support, including the Fund's emergency assistance, have helped offset balance of payments pressures so far, with official reserves rising by about US $\$ 16$ million between October 2009 and February 2010 to US\$130 million (4 months of prospective import cover).

\section{OUTLOOK AND RISKS}

8. As a result of the tsunami, real GDP is expected to contract about 3 percent this financial year and the current account deficit is set to widen substantially.

- $\quad$ The tourism sector, including small beach fales (typical for Samoa), has been severely hit. Based on cross-country recovery experience and Samoa-specific patterns of tourism demand, staff estimates that about $1 \frac{1 / 2}{2}-3 \frac{1}{2}$ percent of GDP could be lost in the first year after the tsunami. ${ }^{1}$ Beyond tourism, the widespread damage to physical infrastructure implies that other key sectors such as commerce, transport, and communication are also directly hit.

- However, with economic activity returning to normal and infrastructure rehabilitation spending providing a further boost, growth could increase significantly in 2010/11 before converging to potential (Table 2).

- Shortfalls in tourism receipts and a sharp increase in capital goods and other imports related to infrastructure rehabilitation would result in a widening of the current account deficit to about 20 percent of GDP in 2009/10 and 2010/11 (Table 3).

\footnotetext{
${ }^{1}$ See Selected Issues Paper, "Samoa: The Impact of the 2009 Tsunami on Tourism and the Economy".
} 
- $\quad$ Headline CPI inflation is expected to decline further and likely to remain close to zero for the remainder of FY2009/10 on base effects from lower global food and commodity prices and unusually strong local food supply. The large share of underemployed in the labor force and the high import content of reconstruction inputs are expected to

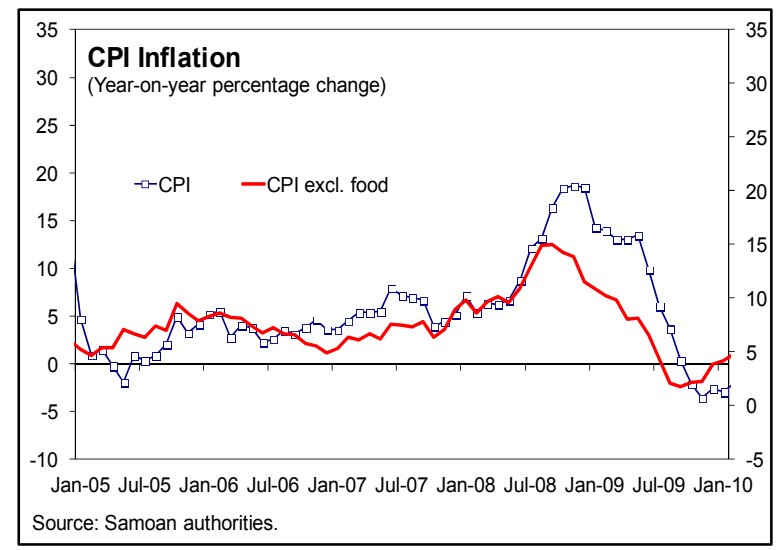
mute undue inflation pressures from tsunami-related public and private spending.

9. This outlook is subject to considerable uncertainty.

- $\quad$ First, this relates to the unprecedented scale of the damage. At this early stage of reconstruction, unanticipated bottlenecks or adverse spillovers between different sectors (e.g., infrastructure rehabilitation and tourism) may emerge, making it difficult to predict the recovery path.

- Moreover, Samoa's image as a safe tourist destination may have suffered, and it remains exposed to natural disasters.

- While the global recovery remains fragile, a stronger-than-anticipated recovery of regional economies and a favorable response to upcoming international rugby and other sporting events in Samoa could, however, result in stronger-than-anticipated remittances and tourism revenue.

- $\quad$ Moreover, the uncertainty surrounding this outlook is compounded by weaknesses in Samoa's national accounts. These may result in a potential for underestimating the contribution of the tourism sector and an overstatement of manufacturing. ${ }^{2}$

\section{Policy Discussions: Returning to Sustained Growth}

10. Policy discussions focused on the need for strong and coordinated efforts at every policy level to return Samoa to sustained growth: (1) the central role of fiscal management in supporting the rebuilding effort while also maintaining public debt sustainability; (2) prudent monetary and exchange-rate management to underpin a sound macroeconomic framework; and (3) structural reform to make the private sector the engine of growth.

\footnotetext{
${ }^{2}$ One important factor is that the 2000 benchmark surveys for the production-based national accounts are likely outdated, resulting in underweight for those sectors that grew rapidly in recent years, such as tourism.
} 


\section{A. Fiscal Management: From Rebuilding to Maintaining Sustainability}

11. The fiscal challenges from emergency relief and rehabilitation are daunting. The government has adopted an economic recovery framework for four years through 2012/13 with a fiscal cost of about US $\$ 100$ million (18 percent of GDP). This not only includes resettlement to safer areas and repair of infrastructure to allow access to basic social services, but also provides for social safety nets, and investments in disaster risk reduction.

\section{The government is committed to minimize the fiscal burden and capacity risks} arising from rehabilitation and maintain fiscal sustainability. Samoa has a good track record in prudently managing public debt, almost all of which is external. The team and the authorities agreed that the government's fiscal strategy as laid out in its letter of intent supporting the November 2009 request for emergency financial assistance from the IMF continues to be appropriate (IMF Country Report No. 10/46). The key policies in the face of the current challenges include:

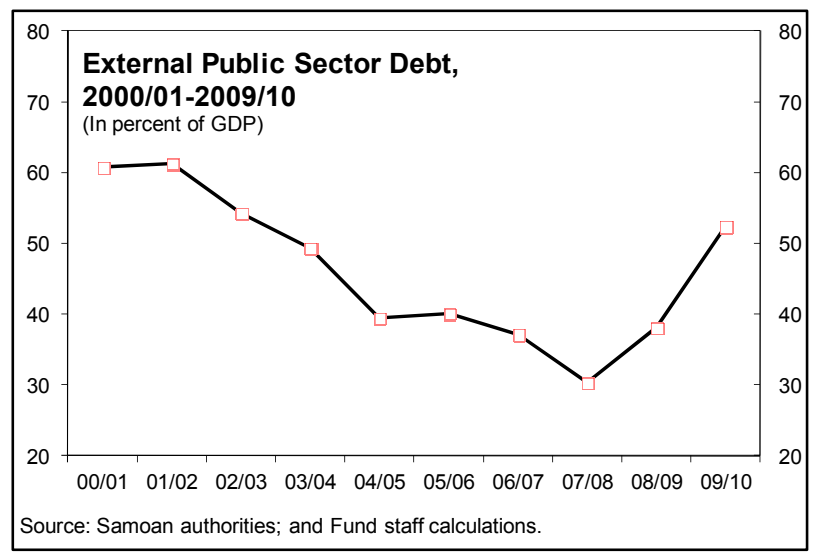

- Securing concessional donor support and prioritizing spending plans. The government has already identified 60 percent of the funding needs for the four-year recovery framework in new grants and concessional financing. It has adopted a supplementary budget for FY 2009/10, which covers a quarter of the recovery framework, is fully funded by grants and concessional loans, and focuses on infrastructure that is key to resuscitate growth, such as utilities and tourism, as well as basic social needs.

- $\quad$ Returning to the public deficit target. A widening of the fiscal deficit to 10 percent of GDP in FY 2009/10 and an average of 7 percent of GDP the following 3 years of reconstruction is unavoidable (Table 4). However, in line with their debt strategy, the authorities intend to reduce the fiscal deficit to less than 3 percent of GDP once tsunamirelated reconstruction is completed in 2013. This would stabilize the net present value of public debt at about 40 percent of GDP - a comfortable level, providing room to absorb future shocks (Supplement 1: Joint IMF/World Bank Debt Sustainability Analysis 2010).

13. Despite indications of a favorable budget outturn, fiscal risks remain that will require strong efforts to underpin the government's commitment.

- A better than initially budgeted outturn for the first half of FY 2009/10 will likely curtail tsunami-related fiscal pressures in the near-term. Revenue performance has been on target as tsunami-related import-duty exemptions were kept at a minimum 
and car imports boomed after the road switch (from right to left in 2009). Development spending under the initial budget has been delayed, reflecting capacity constraints and a reprioritization of spending execution towards reconstruction under the supplementary budget.

- $\quad$ However, the remaining tsunami-related fiscal financing gap is substantial, about 7 percent of GDP, and will need to be filled from the 2010/11 budget onwards. The team and the authorities agreed that every effort should be

\begin{tabular}{|c|c|c|c|c|}
\hline \multicolumn{5}{|c|}{$\begin{array}{l}\text { Samoa: Fiscal cost of tsunami and financing } \\
\text { (In percent of GDP) }\end{array}$} \\
\hline & $2009 / 10$ & 2010/11 & $2011 / 12$ & $2012 / 13$ \\
\hline Cost of recovery plan & 5.2 & 4.7 & 3.8 & 3.9 \\
\hline Current aid pledges & 6.4 & 3.1 & 0.9 & 0.0 \\
\hline Grants & 4.7 & 0.0 & 0.0 & 0.0 \\
\hline Concessional external financing & 1.7 & 3.1 & 0.9 & 0.0 \\
\hline Remaining financing need $1 /$ & -1.2 & 0.4 & 2.9 & 3.9 \\
\hline Memorandum item: & & & & \\
\hline Overall fiscal deficit (including grants) & 9.7 & 9.5 & 5.6 & 5.2 \\
\hline
\end{tabular}
made to secure more grants and concessional loans in filling this gap. If the gap were to be filled on non-concessional terms, the net present value of Samoa's public debt could increase by 5 percent of GDP over the current baseline. This would reduce Samoa's ability to absorb future shocks without risking an unsustainable debt burden.

\section{The authorities concurred with staff advice that existing medium-term} development spending plans should also be reviewed. In consultation with key donors, redirecting to the extent possible funds to rehabilitation would not only help close the financing gap in outer years, but also mitigate capacity constraints in government administration. Delays are becoming evident in the slow implementation of projects under the initial 2009/10 budget. The staff emphasized that restraint on recurrent non-priority expenditure and on any general public wage increase is also required.

\section{The authorities and staff agreed on the need to implement the government's} public financial management reform plan. The team welcomed the recent improvements in tax administration with revenue collection slightly better than budgeted and called for a quick resolution of remaining income tax arrears. Likewise, timely application of the new procurement guidelines designed with donor technical assistance will allow Samoa to adopt international best practice and reduce the potential for wasteful spending.

\section{B. Monetary and Exchange Rate Policy: Managing a Sound Framework}

\section{The team supported the government's commitment to the currency basket peg.}

- $\quad$ The basket peg regime remains credible. In spite of the severe shocks from the global recession and tsunami, official reserves continued to increase and CPI inflation has returned to low levels. At the same time, the tala exchange rate does not appear to be out of line with fundamentals; although, in recent years, it has appreciated markedly 
in real effective terms as the nominal effective rate has remained stable (Figure 2 and Box 1).

- $\quad$ Against this background, the mission welcomed the practice of the Central Bank of Samoa (CBS) to regularly assess the weights in the basket and the level of the exchange rate with a view to maintaining external competitiveness. The team and the authorities agreed that the CBS should use the discretion it is afforded by law to make exchange-

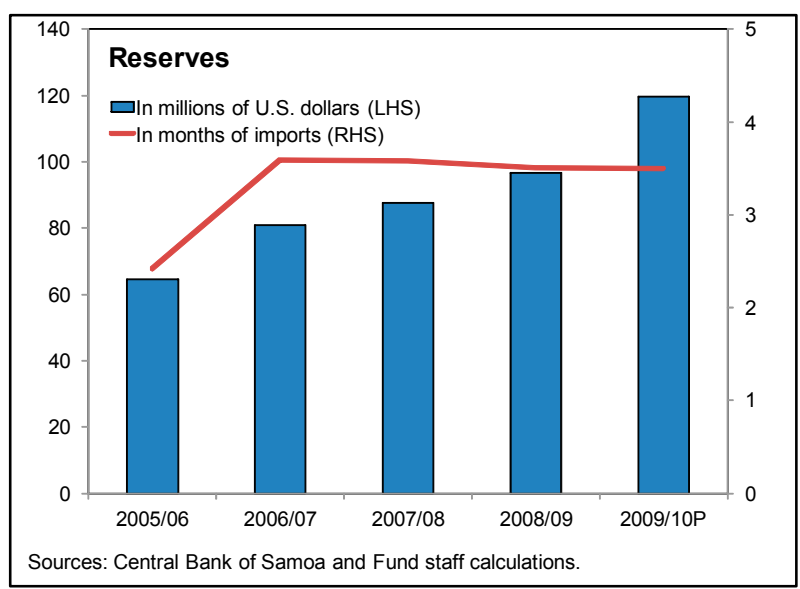
rate adjustments in response to future terms of trade shocks or if the impact of the tsunami on tourism turns out to be more severe and long lasting. ${ }^{3}$ This flexibility would help avoid the need for undue fiscal tightening during the reconstruction period.

\section{The current monetary stance with historically low policy interest rates is} appropriate, given the need to support the economic recovery. However, as the global recovery gains traction and regional central banks withdraw monetary stimulus, the CBS agreed with the team's advice that it should in time move to a more neutral stance. A careful balance will need to be struck between avoiding pressures on foreign exchange reserves from negative interest-rate differentials and providing continued support to the economic recovery. Although capital controls afford the CBS some influence over monetary conditions, the benefits are limited. The mission noted that the pass-through of the CBS' policy rate cuts since August 2008 to commercial lending rates has been low by international standards owing to structural impediments amplifying risk aversion of banks in the downturn (Figure 2). ${ }^{4}$

\section{Structural Reform: Promoting Private-Sector Led Growth}

\section{Over the past two decades, structural reforms have helped make Samoa a more} attractive place to do business. The team welcomed recent reforms to simplify company formation and business registration processes that have lowered the overall cost of starting a

\footnotetext{
${ }^{3}$ The CBS undertakes the review of the currency basket once a year, and there are no statutory requirements as to the composition and the weights of the basket. The CBS can make single discretionary exchange-rate adjustments of up to $+/-2$ percent against the currency basket without cabinet approval. While there is no formal limit on the frequency of such adjustments, it is understood that the CBS would request cabinet approval for larger ad-hoc adjustments.

${ }^{4}$ See Selected Issues Paper "Samoa: Impediments to Bank Intermediation and Monetary Transmission".
} 
Figure 2: Selected Exchange Rate and Financial Indicators

The tala has remained stable in nominal effective terms.

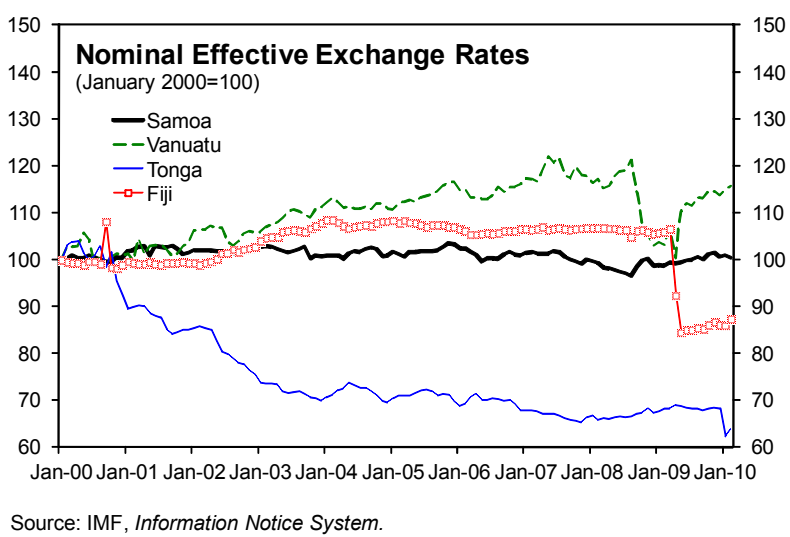

The central bank lowered policy rates early in the crisis, but lending rates did not follow...

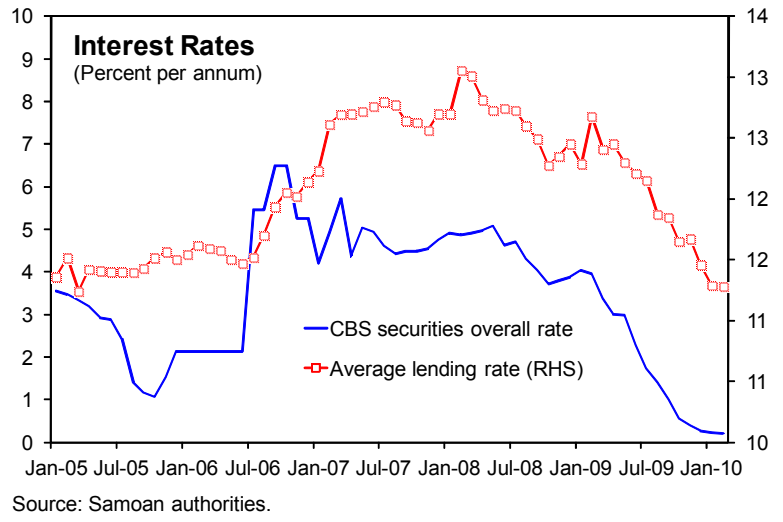

Credit growth to the private sector has remained on its downward trend...

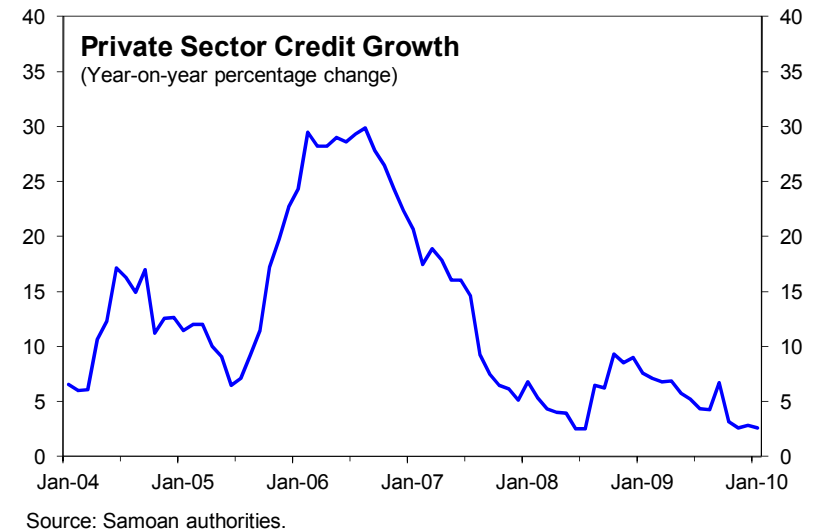

After a substantial real effective appreciation in 2008, the tala has returned closer to trend since mid 2009.

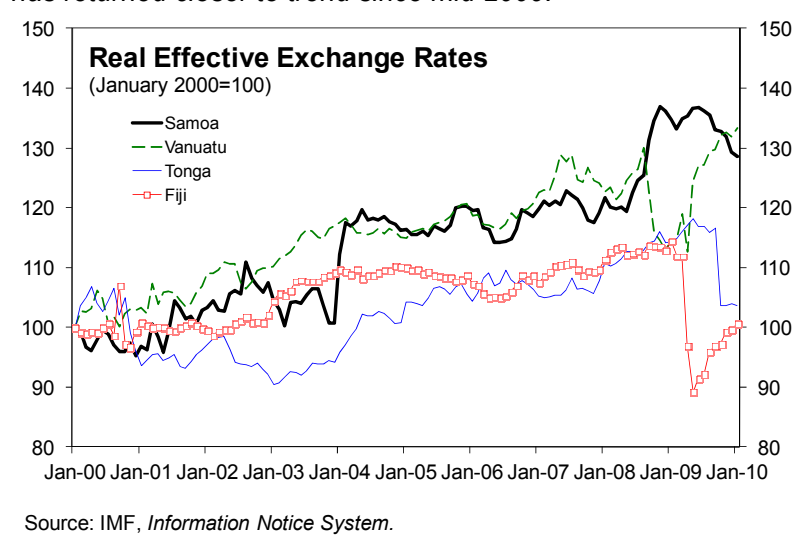

...given increased risk-aversion by banks and widening deposit-lending spreads.

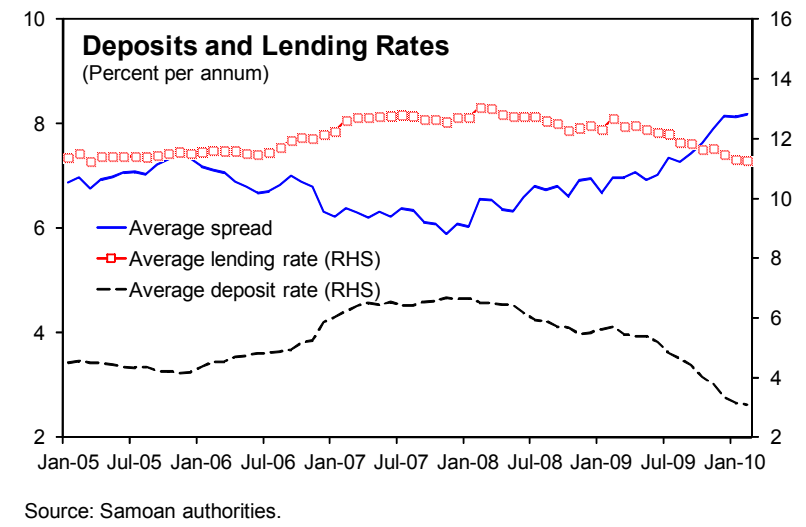

....and bank intermediation levels are still low by international standards.

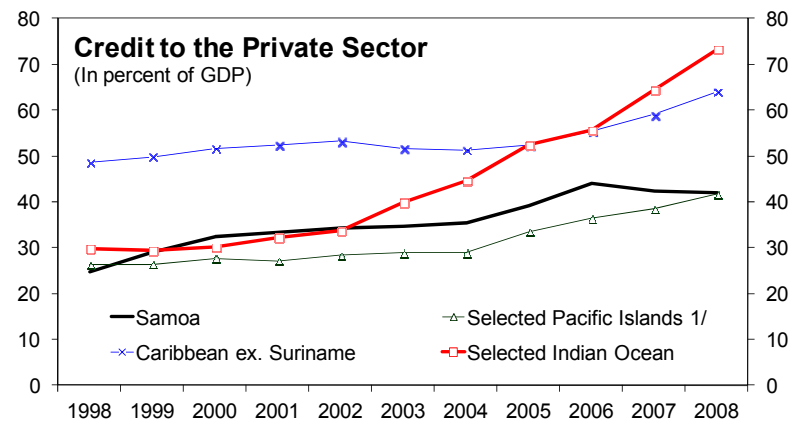

Source: Samoan authorities; IMF, International Financial Statistics. 1/ Comprises Fiji, Papua New Guinea, Samoa, Solomon Islands, Tonga and Vanuatu. 
new business by three quarters. However, further reforms to foster private-sector led economic growth - a key goal of the Strategy for Development of Samoa - are needed to help ensure sustainable economic growth.

\section{The team and the authorities broadly agreed that reforms to facilitate the} economic use of customary land and reduce the role of state-owned enterprises (SOEs) in the economy would contribute significantly to a more vibrant private sector. However, the authorities cautioned that any reform must be equitable and in keeping with Samoa's social and traditional values.

- Use of customary land. The lack of clear legal title to customary land, which accounts for about 80 percent of all land in Samoa and an inability to transfer ownership inhibit its economic use (Box 2). The government has appropriately focused on reforms to ease land registration. The passage of legislation to allow banks to use capital improvements on leased customary land as collateral is also a step in the right direction to improve investors' access to credit. Continued community outreach will be necessary to realize the full benefits of these reforms. However, the team noted that legislation to cap the rise in the market value of freehold land, which reflects its scarcity value, should be avoided. The authorities broadly agreed with the need to pursue further land-use reforms, but emphasized that they need to be carefully calibrated with maintaining Samoa's cultural heritage and social traditions.

- SOE reform. SOEs are placing a significant strain on the Samoan economy and the government's budget (Box 3). The team welcomed the Prime Minister's effort to reinvigorate the reform agenda. In particular, further efforts need to be made to enforce hard budget constraints and implement existing corporate governance legislation including through more clearly defined community services obligations (CSO) met by SOEs. The mission welcomed progress made in bringing selected SOEs to privatization, including SamoaTel. The authorities agreed that, given that existing public debt is on concessional terms, proceeds from the sale of SOEs should go towards deficit reduction and filling the remaining tsunami-related fiscal financing gap.

20. A vibrant private sector will also require a deeper and sound financial system. As the ratio of nonperforming loans has risen from 6 percent at end-2008 to over 8 percent at end-2009, risk aversion of banks has been amplified by structural weaknesses that have hampered credit intermediation and effective risk management (Table 5). Chief among them are lingering uncertainties in the enforcement of land-related collateral and the lack of a credit bureau. Given the urgency caused by the tsunami in improving access to credit, the team supported the government's subsidized loan program for small operators in the tourism 
sector. ${ }^{5}$ However, the team emphasized and the authorities concurred that such schemes should be strictly limited to avoid undue budgetary risks or distortions that hamper longerterm growth prospects. In addition, there was agreement that as the financial system evolves, it will be important to further strengthen financial system supervision and regulation to better gauge vulnerabilities of banks and nonbank financial institutions.

\section{Building on improvements in compilation and dissemination of key economic} statistics will serve to enhance policy credibility and reduce uncertainty for the private sector. Samoa is the only Pacific island that disseminates monthly and quarterly economic statistics through government websites. Yet data are subject to frequent revisions, owing to weaknesses in compilation and coverage, complicating economic analysis. The team welcomed the government's use of technical assistance, including through PFTAC, and noted that improvements to national accounts and the coverage of BOP data are priorities.

\footnotetext{
${ }^{5}$ The program amounts to T5 million (1/2 percent of GDP). For further details see Selected Issues Paper "Samoa: Impediments to Bank Intermediation and Monetary Transmission".
} 


\section{Box 1. SAMOA: EXChange RATE ASSESSMENT}

Excluding the impact of the tsunami, the current account deficit appears to be in line with Samoa's structural savings-investment norm. Once the tsunami-related recovery is completed, Samoa's current account deficit is projected to decline to about 9 percent of GDP in 2013/14. While sensitive to assumptions on key variables, such as population growth, staff estimates based on a sample of 55 low-income countries suggest a savings-investment norm of about 6-10 percent of GDP for Samoa.

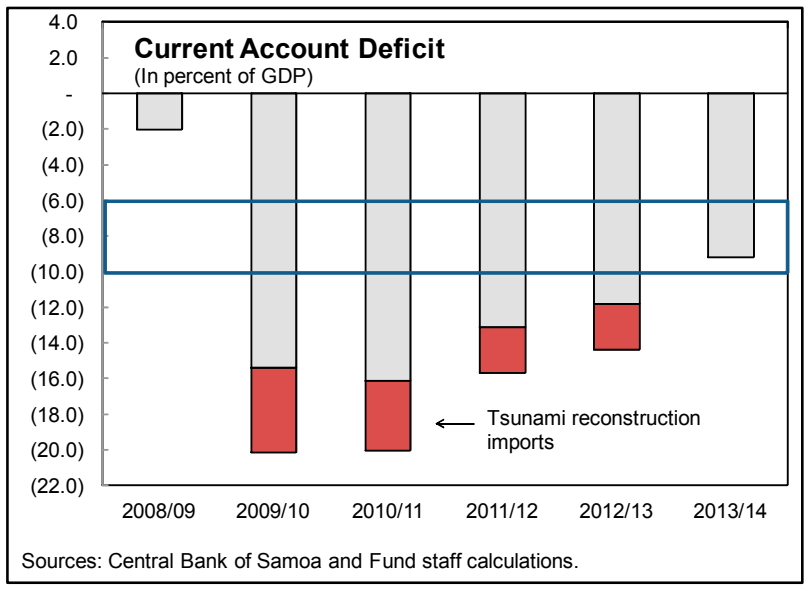

\section{Other indicators of a deviation of the exchange rate from medium-term fundamentals do not point to a misalignment:}

- Foreign reserves rose steadily in recent years and are now about double their level just four years ago. Staff project reserves to remain around $3 \frac{1}{2}-4$ months of imports of goods and services at the end of this fiscal year.

- Tourism receipts have risen at double-digit rates over the last several years in part due to the introduction of new airline flights. They have become Samoa's most important commercial foreign exchange earner (equivalent to about 20 percent of GDP). Indeed, Samoa has gained market share in the main tourist markets from 2004-2008 vis-à-vis other Pacific island countries and its real per-capita income growth over 1993-2008 has been higher than for other tourism-based economies ( $3 \frac{1}{2}$ percent compared with less than 1 percent for other Pacific islands, and about 2 percent for the Caribbean).

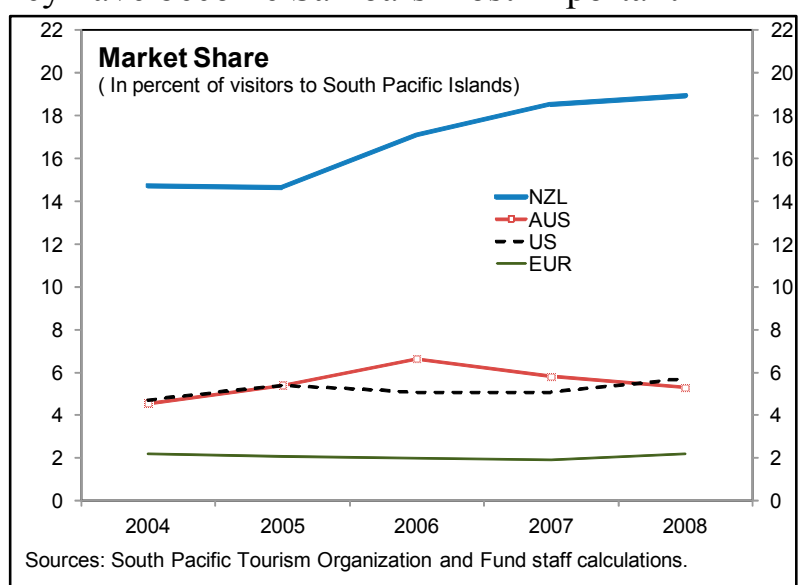

- The decline in fish exports (nearly 20 percent between 2007 and 2009) mainly reflects supply-side factors. Moreover, although fish exports are the second most important commercial activity, they are only equivalent to 4 percent of tourism earnings.

- Remittances, which account for about 25 percent of GDP, have performed strongly over the last several years, reaching an all time high in 2007/08. Importantly, remittances have remained stable during the global financial crisis, and increased in the immediate aftermath of the September 2009 tsunami, underscoring the role of remittances as a shock absorber. 


\section{Box 2. SAMOA: TAPPING The ECONOMIC Potential of CUSTOMARY LAND}

The nature of land ownership in Samoa inhibits economic development. Customary land, which is owned by extended families represented by their chiefs, accounts for around 80 percent of Samoan land. ${ }^{1}$ The chiefs direct the use of the land, giving entitlements to access land, although customary ownership rights flow from a mix of titles and ancestral transfers. The land cannot be transferred outside a village or turned into free hold land. As is the case in other Pacific island countries, establishing clear title to the land is costly and time consuming. Leases are legally possible ${ }^{2}$, but are time consuming and expensive to arrange.

\section{The government recognizes that increasing access to customary land for} development is important and has undertaken legal and policy reforms to this end. ${ }^{3}$ In conjunction with a public outreach campaign, recent reforms have focused on facilitating land registration. In addition, legislation passed in the last couple of years allows banks to use leasehold improvements on customary land as collateral; however, no bank has done so, largely because of the uncertainty associated with contract enforcement.

\section{Moreover, a new land registration system was introduced in March 2009, but less} than 10 percent of the land has been registered so far. This reflects the difficulty and cost, in terms of time and money, in establishing title to land, which requires land owners to advertise notice of intent to title property for three months and survey the land. Disputes over land titling are handled through the Land and Titles Court and can take years to resolve.

The pace of reform is likely to remain slow and deliberate. The government's reform effort is tempered by a desire to foster balanced and equitable growth and a respect for Samoa's traditional values and culture. In addition, the government's commitment to address a key impediment - the inalienable nature of customary land - is unclear. Looking ahead, practical and likely politically feasible reforms the government could consider are establishing a "one stop shop" for customary land matters, developing a database of leased and leasable land and continuing its outreach efforts and encouragement of land registration.

\footnotetext{
${ }^{1}$ The government owns 11 percent of the land through the several agencies, including the Samoa Land Corporation, the Samoa Trust Estate Corporation, and the Land Board. The government seeks to increase access to this land through issuing leases. The remaining 9 percent of the land is freehold.

${ }^{2}$ Customary land can be leased for a 30 year period with an option to renew for another 30 years for hotel development and a 20 year period with the option to renew for another 20 years for all other purposes. The Ministry of Nature Resources and Environment (MNRE) assists landowners and potential investors in the development of customary land, including the drafting of customary land leases.

${ }^{3}$ The Asian Development Bank, through a Japanese trust fund, has recently supported technical assistance in this area.
} 


\section{BOX 3. SAMOA: STATE-OWNED ENTERPRISE REFORM ${ }^{1}$}

State-owned enterprises (SOEs) account for 10 percent of formal employment, but constitute a drag on economic growth and the government's budget. For the nonstrategic SOEs that are available for privatization, the return on equity was just 3.3 percent for FY2007/08, compared with the government's own target of 7 percent. In addition to the direct costs to the economy, SOEs divert potential private and public investment away from priority sectors. Ongoing SOE investment and foregone earnings were equivalent to almost 60 percent of health and education expenditure during 200206.

Despite previous achievements, Samoa's SOE reform program has slowed since 2007. Privatization is continuing, albeit slowing with the removal of Agricultural Stores Corporation from the privatization pipeline after it had received initial privatization preparation support and the delays associated with the sale of Samoa Shipping Services. The privatization of SamoaTel is currently targeted to be completed before the end of 2010. The combined book value of companies slated for privatization is about T70 million (FY2007/08) or 4 1/2 percent of GDP.

Regardless of ownership, the key to successful SOE reform in Samoa will be placing SOEs on a fully commercial footing, with independence from political directives, hard budget constraints, exposure to competition, and full accountability. A functioning Community Service Obligation (CSO) framework is vital for the commercialization of SOEs. However, the nature and magnitude of CSOs are not clearly and transparently defined. The Public Bodies (Performance and Accountability) Act enables SOEs to claim reimbursement from the Government for the cost of providing CSOs approved under the provisions of the Act and Regulations. Those provisions, however, are not enforced, resulting in conflicting interpretations of what constitutes a CSO. This contributes to poor CSO management that depresses SOE profitability and reduces their efficiency. SOEs do not currently have the capacity to prepare, or the Government to effectively monitor, CSO contracts.

Existing corporate governance legislation is based on international good practice, but implementation has been challenging. Only the reporting and disclosure requirements are being fully met by the SOEs. Of the other regulations, as of end FY2009, 121 out of the 270 positions available on SOE boards were held by public servants and members of parliament, even though they are prohibited from serving as directors of SOEs in line with good international practice. The implementation of governance and accountability mechanisms will be key to putting SOEs on a commercial footing and improving overall economic efficiency.

\footnotetext{
${ }^{1}$ This box summarizes the main findings of the Selected Issues Paper "State-Owned Enterprise Reform in Samoa".
} 
Table 1. Samoa: Selected Economic and Financial Indicators, 2004/05-2010/11 1/

Population (2008): 0.18 million

Main Exports: Tourism, Fish

GDP per capita (2007/08): US $\$ 2,802$

Quota: SDR 11.6 million

Proj.

2004/05 2005/06 2006/07 2007/08 2008/09 $\overline{2009 / 10 \quad 2010 / 11}$

Est.

Output and inflation

Real GDP growth

Nominal GDP

Change in $\mathrm{CPI}$ (end period)

Change in $\mathrm{CPI}$ (period average)

Central government budget

Revenue and grants

Expenditure and net lending

Of which: Development

Overall balance

External financing

Domestic financing

Money and credit

Broad money (M2)

Net foreign assets

Net domestic assets

Private sector credit

Balance of payments

Current account balance

(In percent of GDP)

Merchandise exports, f.o.b.

Merchandise imports, c.i.f.

Services (net)

Income (net)

Current transfers

External reserves and debt

Gross official reserves

(In months of next year's imports of GNFS)

External debt (in percent of GDP)

Public external debt-service ratio (in percent)

Exchange rates

Market rate (tala/U.S. dollar, period average)

Market rate (tala/U.S. dollar, end period)

Nominal effective exchange rate $(2000=100) 2 /$

Real effective exchange rate $(2000=100) 2 /$

Memorandum items:

Nominal GDP (in millions of tala)

Nominal GDP (in millions of U.S. dollars)

GDP per capita (U.S. dollars)

(12-month percent change)

$\begin{array}{rrrrrrr}7.0 & 2.2 & 2.3 & 5.0 & -4.9 & -2.8 & 3.0 \\ 11.2 & 8.6 & 9.4 & 10.1 & 4.3 & -3.3 & 9.3 \\ 1.0 & 2.1 & 8.0 & 8.8 & 9.8 & -0.6 & 6.0 \\ 7.8 & 3.2 & 4.5 & 6.2 & 14.4 & -0.2 & 3.0\end{array}$

(In percent of GDP)

$\begin{array}{rrrrrrr}36.3 & 31.8 & 36.4 & 30.9 & 32.0 & 39.5 & 33.7 \\ 36.1 & 32.3 & 35.8 & 32.7 & 35.9 & 49.2 & 43.2 \\ 13.1 & 7.1 & 9.3 & 6.5 & 11.9 & 21.4 & \\ 0.3 & -0.5 & 0.6 & -1.8 & -3.8 & -9.7 & -9.5 \\ 1.4 & 0.5 & -1.1 & 0.8 & 2.9 & 10.9 & 8.3 \\ -1.7 & 0.0 & 0.4 & 1.0 & 0.9 & -1.2 & 1.1\end{array}$

(12-month percent change)

$\begin{array}{rrrrrrr}15.0 & 13.0 & 8.7 & 12.3 & 7.6 & \ldots & \ldots \\ 34.4 & -20.2 & 7.8 & 14.4 & 9.0 & \ldots & \ldots \\ -0.7 & 79.8 & -0.5 & 1.3 & 6.7 & \ldots & \ldots \\ 6.8 & 28.2 & 11.7 & 6.5 & 5.2 & \ldots & \ldots\end{array}$

(In millions of U.S. dollars)

\begin{tabular}{rrrrrrr}
-39.1 & -50.3 & -83.1 & -31.3 & -11.4 & -108.7 & -118.2 \\
-9.6 & -11.1 & -15.9 & -6.2 & -2.0 & -20.1 & -20.0 \\
12.8 & 11.0 & 12.2 & 11.2 & 10.2 & 9.0 & 13.4 \\
-168.2 & -204.6 & -241.1 & -204.3 & -227.6 & -301.2 & -329.6 \\
59.7 & 69.9 & 79.3 & 87.1 & 98.0 & 79.2 & \\
-34.1 & -36.2 & -37.5 & -38.0 & -17.4 & -32.5 & \\
90.8 & 109.6 & 103.9 & 112.8 & 125.4 & 136.8 & 148.8 \\
& & & & & & \\
84.2 & 64.4 & 80.9 & 87.6 & 96.6 & 119.6 & 124.6 \\
3.7 & 2.4 & 3.6 & 3.6 & 3.5 & 3.5 & 3.5 \\
39.5 & 40.1 & 37.1 & 30.3 & 38.1 & 52.4 & 58.1 \\
9.3 & 9.8 & 5.2 & 3.9 & 5.1 & 6.3 & 5.7 \\
& & & & & & \\
2.7 & 2.8 & 2.6 & 2.6 & 2.8 & $\ldots$ & $\ldots$ \\
2.8 & 2.7 & 2.6 & 2.9 & 2.8 & $\ldots$ & $\ldots$ \\
101.6 & 100.7 & 100.5 & 98.1 & 99.3 & $\ldots$ & $\ldots$ \\
120.2 & 120.0 & 123.4 & 129.3 & 139.9 & $\ldots$ & $\ldots$ \\
& & & & & & \\
1,124 & 1,221 & 1,336 & 1,472 & 1,536 & 1,485 & 1623 \\
407 & 455 & 522 & 507 & 558 & 540 & 590 \\
2,276 & 2,537 & 2,902 & 2,802 & 3,078 & 2,967 & 3,231 \\
\hline
\end{tabular}

Sources: Data provided by the Samoan authorities and Fund staff estimates.

1/ Fiscal year beginning July 1 .

2/ IMF, Information Notice System (calendar year). For 2009, latest as of June quarter.

\section{CInternational Monetary Fund. Not for Redistribution}


Table 2. Samoa: Illustrative Medium-Term Baseline Scenario, 2005/06-2013/14

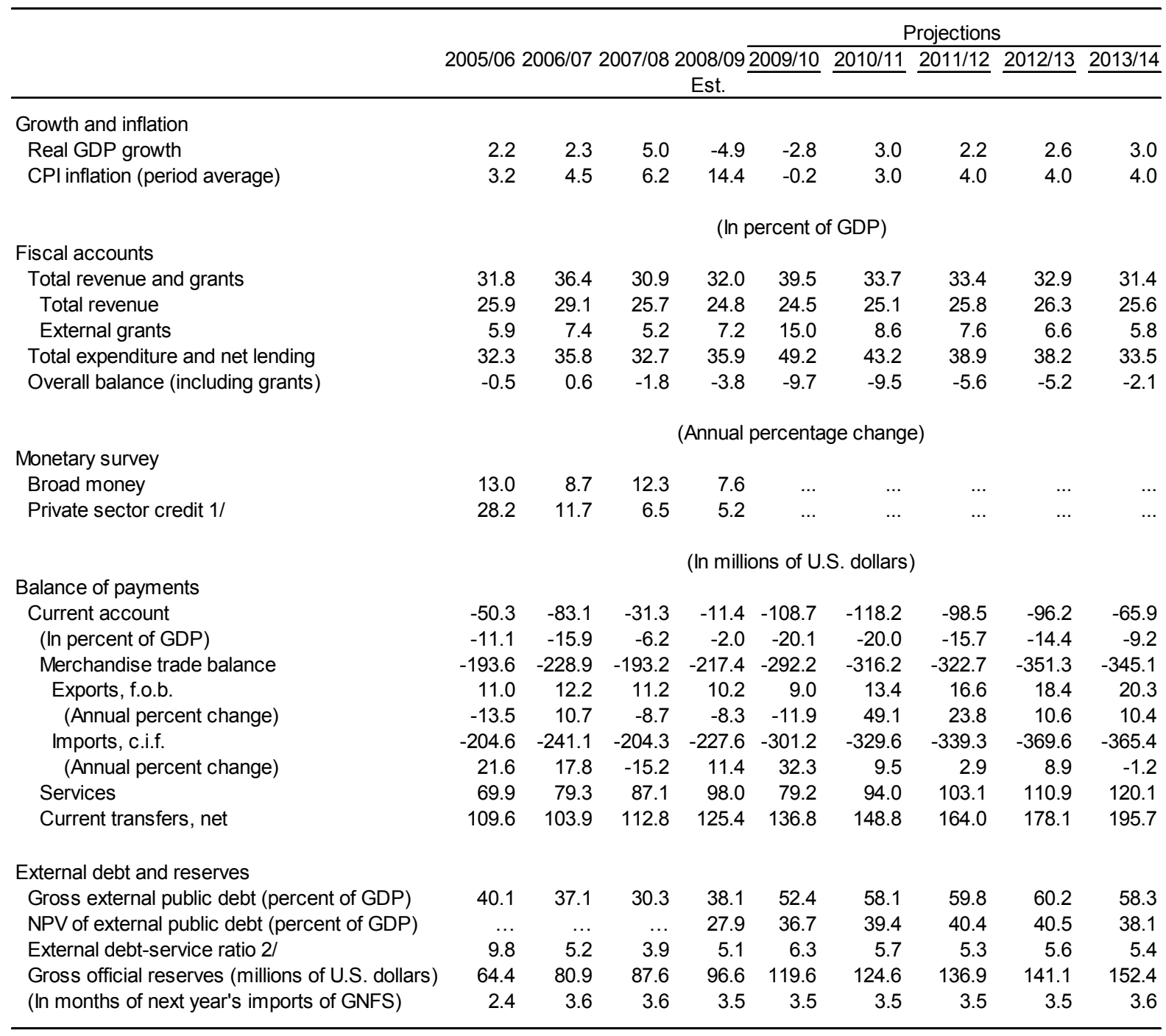

Sources: Data provided by the Samoan authorities and Fund staff projections.

1/ Total credit growth (including credit extended by nonbank financial institutions).

2/ In percent of GNFS exports. 
Table 3: Samoa: Balance of Payments, 2004/05-2010/11

(In million of U.S. dollars, unless otherwise indicated)

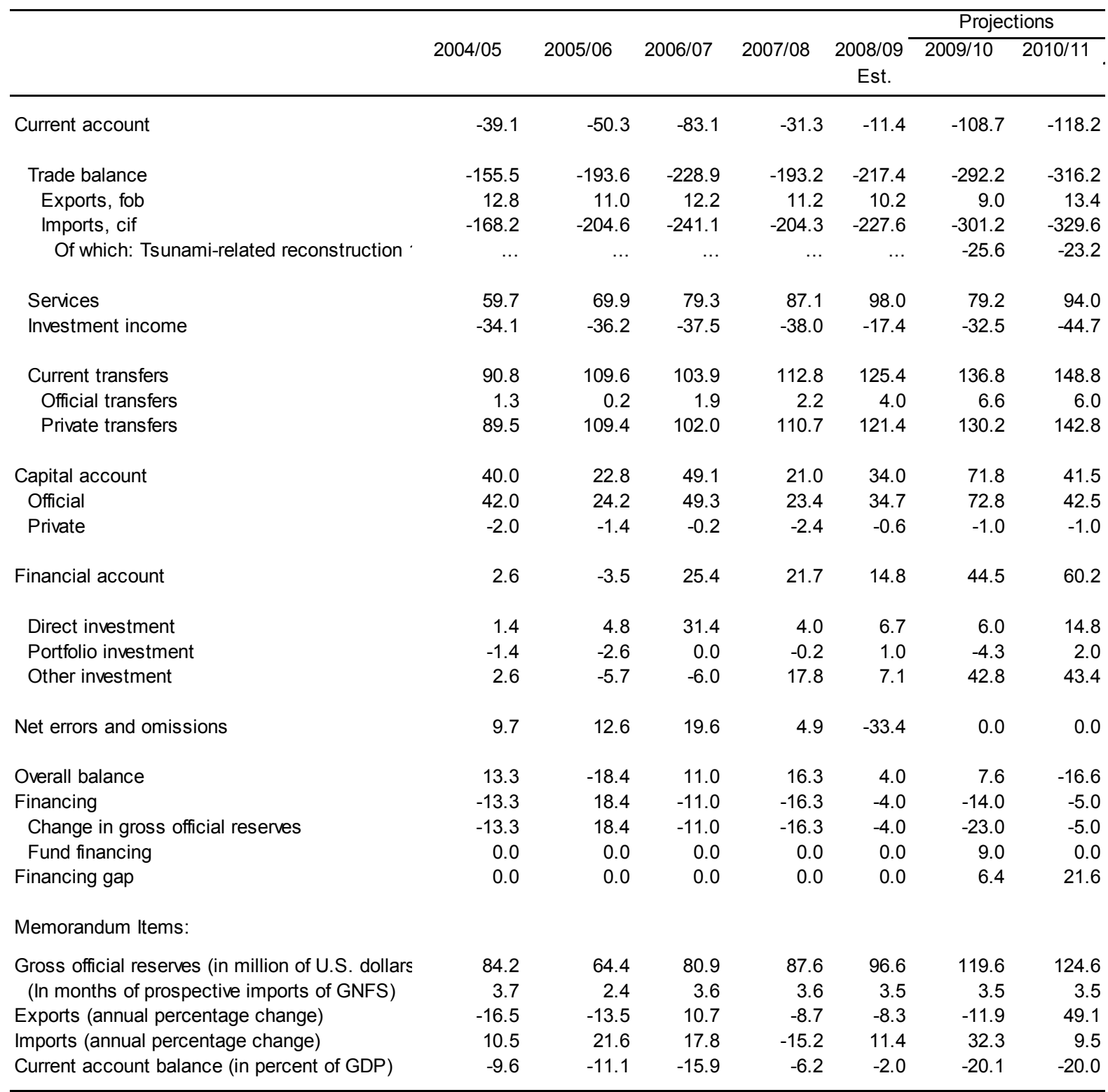

Sources: Data provided by the Samoan authorities and Fund staff estimates.

1/ Based on the government's recovery framework with a total cost for rebuilding and resettlement borne by public and private sectors of US $\$ 120$ million to be phased over four years with import content of about two-thirds. 
Table 4. Samoa: Financial Operations of the Central Government, 2005/06-2010/11

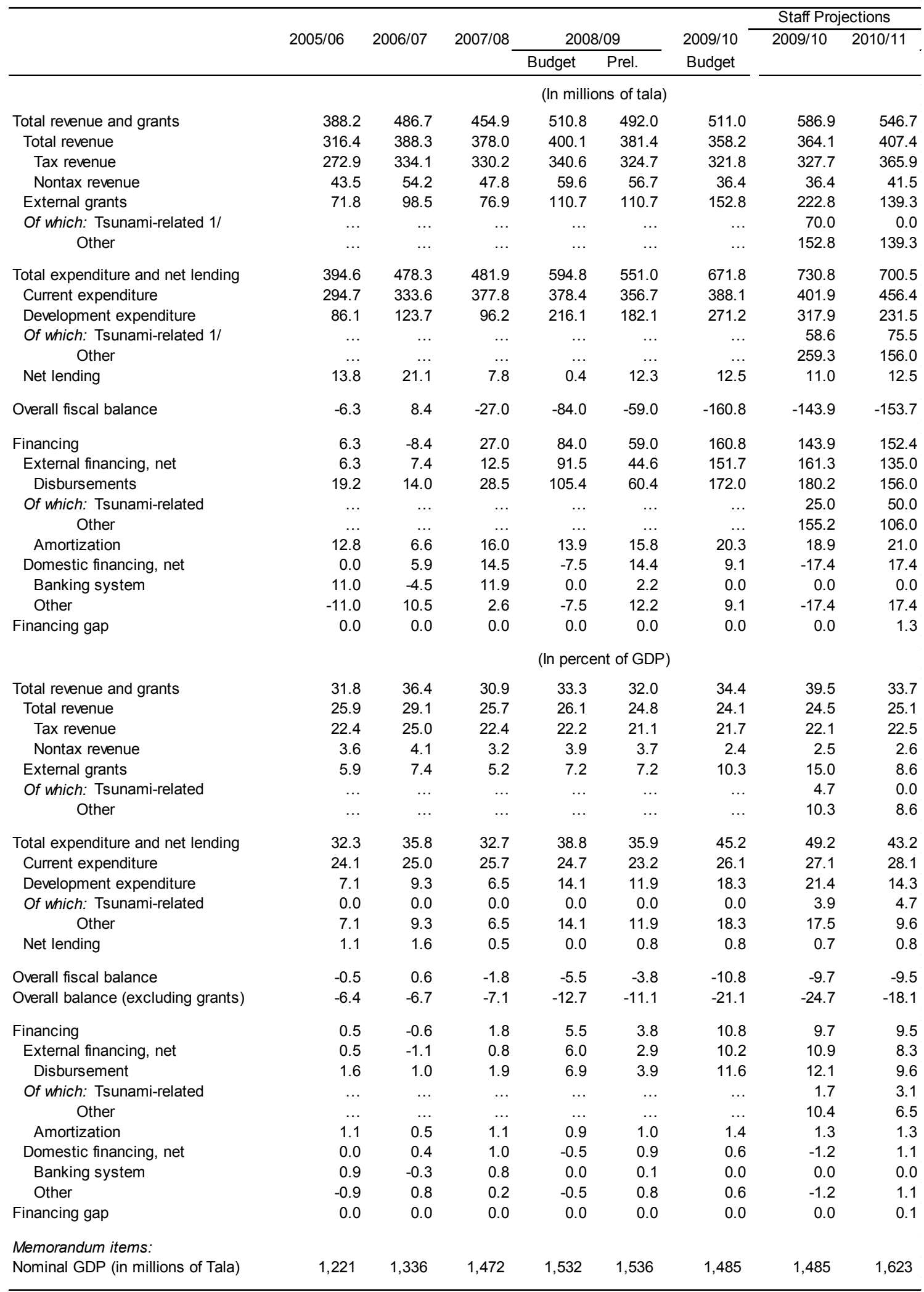

Sources: Data provided by the Samoan authorities and Fund staff estimates.

1 / Based on the government's recovery framework with a fiscal cost of US $\$ 100$ million. 
Table 5. Samoa: Financial Soundness Indicators, 2004-09 1/

\begin{tabular}{lrrrrrr}
\hline & 2004 & 2005 & 2006 & 2007 & 2008 & 2009 \\
& & & & \\
& & \multicolumn{7}{c}{ (in percent) } \\
& 84.1 & 93.8 & 107.4 & 104.8 & 104.5 & 96.4 \\
Loans to deposit ratio & 24.5 & 24.1 & 24.4 & 28.0 & 28.0 & 30.2 \\
Capital to risk-weighted asset ratio & 3.3 & 4.0 & 4.6 & 3.7 & 4.1 & 3.2 \\
Return on assets & 5.3 & 5.4 & 4.0 & 7.1 & 6.0 & 8.1 \\
Non-performing loans ratio & 9.0 & 8.7 & 8.3 & 7.0 & 7.5 & 7.2 \\
Net interest margins & 16.4 & 12.9 & 5.7 & 12.5 & 19.0 & 26.4 \\
Liquid assets to short-term liabilities & 77.6 & 74.4 & 73.2 & 47.6 & 70.0 & 64.0 \\
Bank provisions to non-performing loans & & & & & & \\
\end{tabular}

Source: Central Bank of Samoa.

1/ For commercial banks. 


\title{
INTERNATIONAL MONETARY FUND AND \\ INTERNATIONAL DEVELOPMENT ASSOCIATION
}

\author{
SAMOA \\ Joint IMF/World Bank Debt Sustainability Analysis 2010 \\ Prepared by the staffs of the International Monetary Fund and \\ the International Development Association \\ Approved by Ray Brooks and Aasim Husain (IMF) \\ and Vikram Nehru and Sudarshan Gooptu (IDA)
}

April 22, 2010

Based on the low income country debt sustainability analysis (LIC DSA), Samoa remains at low risk of debt distress. ${ }^{2}$ The overall assessment of debt distress is not substantively different from the last joint DSA (IMF Country Report No. 07/185). Samoa's external and public sector debt remains sustainable even after significant borrowing to finance post-tsunami reconstruction. The present value (PV) of external debt to GDP is projected to peak at 40 percent under the baseline scenario. This leaves a cushion relative to the policy-dependent threshold of 50 percent for Samoa to absorb future shocks. Large worker remittance flows equivalent to 25 percent of GDP provide a further cushion. However, it will remain important for Samoa to continue seeking concessional financing. Borrowing on non-concessional terms to finance reconstruction would significantly eat into the borrowing cushion.

\section{BACKGROUND}

1. The external and public debt sustainability analyses are based on the standard LIC DSA framework. ${ }^{3}$ The DSA presents the projected path of Samoa's external- and

\footnotetext{
${ }^{1}$ This DSA was prepared jointly with the World Bank, and in collaboration with the Asian Development Bank, in accordance with the Debt Sustainability Framework for low-income countries approved by the Executive Boards of the IMF and IDA. The debt data underlying this exercise were provided by the Samoan authorities.

${ }^{2}$ Samoa is classified as a "strong performer" according to the three-year average of IDA's Country Policy and Institutional Assessment (CPIA) index under the joint IMF/IDA debt sustainability framework. The thresholds for "strong performers" are: 50 percent for PV of debt to GDP; 200 percent for PV of debt to exports; 300 percent for $\mathrm{PV}$ of debt to revenues; 25 percent debt service to exports; and 35 percent debt service to revenues.

${ }^{3}$ See "Debt Sustainability in Low-Income Countries: Proposal for an Operational Framework and Policy Implications" (http://www.imf.org/external/np/pdr/sustain/2004/020304.htm and IDA/SECM2004/0035, 2/3/04), "Debt Sustainability in Low-Income Countries: Further Considerations on an Operational Framework and Policy Implications" (http://www.imf.org/external/np/pdr/sustain/2004/091004.htm and IDA/SECM2004/0629,
}

(continued) 
public-sector debt burden indicators, and draws some conclusions on the forward-looking sustainability of debt.

\section{Samoa's pre-tsunami stock of external debt as of June 2009 was relatively low.}

The stock of external debt was below 40 and 30 percent of GDP in nominal and present value terms, respectively. Virtually all of Samoa's public debt is external. The stock of domestic public debt is small, around 2.3 percent of GDP in nominal terms composed mainly of stateowned enterprise debt for which the government has assumed responsibility. The government has not issued any domestic debt since 2006. Contingent liabilities related to existing guarantees on the state-owned enterprise (SOE)'s stock of debt amount to about 1.1 percent of GDP in nominal terms. Together with interest-only guarantees on SOE debt, contingent liabilities amount to about 1.2 percent of GDP on present value terms (Table 1a).

\section{Multilateral debt comprises the vast majority of the debt stock. The Asian} Development Bank is the largest creditor with claims amounting to 41 percent of Samoa's external debt stock. The largest bilateral creditor is China, which holds 16 percent of Samoa's external debt.

4. Samoa pursues a sound public debt management strategy. Quantitative targets are set to keep nominal net public debt at less than 40 percent of GDP and the government actively seeks to borrow on concessional terms. In addition, a recent World Bank Debt Management Performance Assessment identified a number of strengths particularly in the areas of governance of debt and the overall debt management strategy. It also noted a few areas that required further attention, including the need for a single Treasury account to improve cash management. ${ }^{4}$

\section{BASELINe SCENARIO}

5. The baseline scenario assumptions are presented in Box 1. The financing requirement for the post-tsunami recovery framework leads to a sizeable buildup in the stock of external debt over the near to medium term. This build up is incorporated into the baseline scenario for the updated debt sustainability analysis and includes IMF financing provided in December 2009 under the Exogenous Shocks Facility amounting to 3 percent of Samoa's external debt. Nonetheless, the debt ratios remain within their policy dependent thresholds (50 percent of GDP for low risk of debt distress rating) under the baseline scenario. The baseline also assumes that the authorities, as is their intention, approach donors to request additional support in the form of grants and concessional loans to cover the projected financing gaps.

9/10/04), and reference to "Staff Guidance Note on the Application of the Joint Bank-Fund Debt Sustainability Framework for Low-Income Countries" (http://www.imf.org/external/pp/longres.aspx?id=4419).

${ }^{4}$ Debt Management Assessment Performance prepared by the World Bank (January 2010). 


\section{BoX 1. KeY ASSUMPTIONS}

Real GDP growth: Real GDP is projected to contract about 3 percent in the first year after the September 2009 tsunami, which severely hit the tourism sector. However, with economic activity returning to normal and post-tsunami infrastructure rehabilitation spending providing a further boost, GDP growth could converge quickly to its long-run potential, which is assumed to be 3 percent, slightly below historical averages.

Inflation: The change in the average CPI is expected to decline to around zero percent $y / y$ at the end of FY 2009/10 on base effects from lower global food and commodity prices and unusually strong food supply before returning towards its long-run average as economic growth picks up in 2011 and beyond.

Fiscal balance: The government's post-tsunami economic recovery framework for the four years through 2012/13 has a fiscal cost of about 18 percent of GDP. As a result, the fiscal deficit is projected to widen to 10 percent of GDP in FY 2009/10 and average 7 percent of GDP the following three years of reconstruction. However, the government remains committed to reducing the fiscal deficit to less than three percent of GDP once reconstruction is completed in 2013.

External sector: The non-interest current account deficit will also widen significantly in FY 2009/10 on the back of tsunami-related reconstruction imports and a fall in tourism receipts and remain elevated through 2013, when reconstruction is expected to be completed. Net FDI inflows as a percent of GDP is assumed to grow very gradually to 7 percent of GDP at the end of the projection period, as the tourism sector develops further and investment levels converge with those in other Pacific islands.

Financing flows: The government has secured donor commitments to finance tsunamirelated expenditures into FY 2010/11 and is committed to seeking concessional assistance to finance the remainder of the economic recovery framework. Remittances remained stable during the global financial crisis, and are expected to remain significant throughout the projection period, growing in line with source countries' income. No financing from privatizations, commercial loans, or short-term loans is assumed throughout the period.

\section{EXTernal Debt Sustainability Analysis}

\section{Baseline}

6. Under the baseline, Samoa's external debt burden indicators remain below the indicative thresholds, which is consistent with debt sustainability throughout the projection period. The PV of external debt to GDP peaks at slightly over 40 percent in 2013 and then gradually falls to 25 percent in 2030 - well below Samoa's policy-dependent 
threshold level of 50 percent. The present value of debt to exports and debt service to exports remain below their relevant thresholds. If remittances were added to the denominator for debt service, the ratio would be well below 3.5 percent throughout the projection period compared to a policy-dependent threshold for debt-service to exports of 25 percent. The baseline ratios exceed those generated under a scenario where the key variables are set at their historical averages because GDP and export growth under the baseline scenario are below their historical averages.

\section{Relative to the last staff report on the authorities' ESF/RAC request after the} 2009 Tsunami (IMF Country Report No. 10/46) the external debt-to-GDP and external debt-to-exports ratios differ only slightly. Specifically, the present value of external debt to GDP is a little higher due to a lower projected nominal GDP growth, while the present value of external debt to exports is somewhat lower because of a greater concentration of grant financing in 2009 and 2010 than was assumed in IMF Country Report No. 10/46. In addition, exports of services are projected to be slightly higher in FY2009/10 due to an unexpected temporary increase in volunteer arrivals in the first quarter of the year and additional sporting events (Table 2a).

8. Under the various bound tests, the ratios remain manageable for the shocks considered (Table 2b and Figure 1). The combination shock using one-half standard deviation shocks for real GDP and export value growth and the U.S. dollar deflator is the most extreme shock. Only the PV of debt-to-GDP peaks above its respective indicative threshold of 50 percent before falling back below the threshold by 2020. If remittances are included, the PV of debt-to-GDP-and-remittances ratio peaks above the lower modified threshold of 45 percent for only four years before falling below the modified threshold in 2016 (Figure 3). All other indicators remain below, often by a wide margin, their thresholds.

\section{Non-concessional borrowing}

9. Staff also made calculations in which the remaining tsunami-related financing gap is filled on non-concessional terms. The main purpose of these calculations is to illustrate that, notwithstanding a generally favorable debt outlook, the authorities' commitment to only seek concessional assistance to finance tsunami-related reconstruction is appropriate. Staff assumed the authorities could borrow at 9.25 percent per annum for a term of five years, similar to the terms on Senegal's euro-bond issued in December 2009. The additional cost associated with non-concessional borrowing would absorb a significant portion of the cushion provided for borrowing in the event of a shock under the baseline scenario. Specifically, nonconcessional borrowing adds about five percentage points of GDP to the present value of external debt to GDP relative to the baseline. This would leave a cushion of less than four percent of GDP for additional borrowing in the event of shock before the present value of external debt-to-GDP ratio would breach the policy-dependent threshold. 
Samoa: Present value of public sector debt under baseline and non-concessional borrowing scenarios (In percent of GDP)

\begin{tabular}{lrrrr}
\hline & $2009 / 10$ & $2010 / 11$ & $2011 / 12$ & $2012 / 13$ \\
\hline Tsunami-related financing need & -1.2 & 0.4 & 2.9 & 3.9 \\
PV of public sector debt under baseline scenario & 38.6 & 41.0 & 41.9 & 41.8 \\
PV of public sector debt under non-concessional borrowing scenario & 38.6 & 41.4 & 44.3 & 46.6 \\
\hline
\end{tabular}

Source: Fund staff estimates.

\section{Fiscal Debt Sustainability Analysis}

\section{The baseline scenario for the updated public sector debt sustainability now} includes data on SOE debt. The government has guaranteed 12 SOE loans contracted with the Samoa National Provident Fund and two commercial banks. The guarantees are equivalent to about 3.2 percent of GDP. The creditors have exercised guarantees on four of the loans and the government has assumed responsibility for servicing the loans. The rest remain contingent liabilities of the government.

\section{Public sector debt under the baseline scenario ${ }^{5}$ also is sustainable and in line} with the authorities debt management strategy. The present value of public sector debt relative to GDP briefly exceeds the government's target of 40 percent of GDP during the reconstruction period before falling below the target ceiling in 2015 (Table $1 \mathrm{~b}$ and Figure 2). Under this alternative scenario, in which the primary balance is held unchanged from 2010, the PV of debt-to-GDP ratio breaches the policy-dependent threshold in 2014 and continues to rise thereafter and the PV of debt-to-exports ratio follows a similar trajectory. This highlights the need for the government to follow through on its commitment to reduce the fiscal deficit to less than three percent of GDP once reconstruction is completed in 2013. Under all other shock scenarios, the public debt ratios remain below their policy dependent thresholds. ${ }^{6}$

\section{Conclusion}

12. Samoa remains at low risk of debt distress. Although the debt ratios will rise significantly over the next three to four years as the government receives foreign financing to recover from the 2009 tsunami, the debt outlook is expected to remain favorable, given a low initial level of indebtedness, Samoa's track record of prudent macroeconomic management, and assuming the tourism sector returns to trend growth. As a result, the overall assessment of debt distress is not substantively different from the last joint DSA (IMF Country Report

\footnotetext{
${ }^{5}$ The fiscal baseline assumes that creditors do not exercise existing guarantees on SOE debt.

${ }^{6}$ While the PV of debt-to-GDP ratio also exceeds its policy-dependent threshold initially due to a one-time real deprecation, it follows a downward trajectory and drops below 50 percent of GDP in 2015.
} 
No. 07/185). The present value (PV) of external debt to GDP is projected to peak at 40 percent under the baseline scenario. This leaves a cushion relative to the policy-dependent threshold of 50 percent for Samoa to absorb future shocks. Even under the most extreme stress test scenarios, most indicators of debt sustainability, except for the PV of debt-to-GDP ratio, remain below their indicative thresholds, often by a wide margin. Large worker remittance flows equivalent to 25 percent of GDP provide a further cushion. If these are included, the PV of debt-to-GDP-and-remittances ratio remains below its lower modified threshold under all alternative shocks considered except for a very temporary breach of the threshold by a small margin in the combination shock. However, it will remain important for Samoa to continue seeking concessional financing. Borrowing on non-concessional terms to finance reconstruction would significantly eat into the borrowing cushion. 
Table 1a. Samoa: Public Sector Debt Sustainability Framework, Baseline Scenario, 2007-2030 (In percent of GDP, unless otherwise indicated)

\begin{tabular}{|c|c|c|c|c|c|c|c|c|c|c|c|c|c|c|c|}
\hline & \multicolumn{3}{|c|}{ Actual } & \multirow[b]{2}{*}{ Average } & \multirow[b]{2}{*}{$\begin{array}{l}\text { Standard } \\
\text { Deviation }\end{array}$} & \multicolumn{10}{|c|}{ Projections } \\
\hline & 2007 & 2008 & 2009 & & & 2010 & 2011 & 2012 & 2013 & 2014 & 2015 & $\begin{array}{l}2010-15 \\
\text { Average }\end{array}$ & 2020 & 2030 & $\begin{array}{l}2016-30 \\
\text { Average }\end{array}$ \\
\hline $\begin{array}{l}\text { Public sector debt } 1 / \\
\text { o/w foreign-currency denominated }\end{array}$ & $\begin{array}{l}37.1 \\
37.1\end{array}$ & $\begin{array}{l}30.3 \\
30.3\end{array}$ & $\begin{array}{l}40.4 \\
38.1\end{array}$ & & & $\begin{array}{l}54.3 \\
52.4\end{array}$ & $\begin{array}{l}59.7 \\
58.1\end{array}$ & $\begin{array}{l}61.3 \\
59.8\end{array}$ & $\begin{array}{l}61.5 \\
60.2\end{array}$ & $\begin{array}{l}59.4 \\
58.3\end{array}$ & $\begin{array}{l}57.1 \\
56.2\end{array}$ & & $\begin{array}{l}47.7 \\
47.4\end{array}$ & $\begin{array}{l}37.3 \\
37.3\end{array}$ & \\
\hline Change in public sector debt & -3.0 & -6.8 & 10.1 & & & 14.0 & 5.4 & 1.5 & 0.2 & -2.1 & -2.3 & & -1.7 & -0.5 & \\
\hline Identified debt-creating flows & -6.2 & -1.2 & 3.7 & & & 10.8 & 4.9 & 2.0 & 1.4 & -2.0 & -1.6 & & -0.9 & -0.1 & \\
\hline Primary deficit & -1.4 & 1.6 & 3.3 & 0.6 & 1.8 & 8.6 & 8.8 & 4.8 & 4.5 & 1.4 & 1.7 & 5.0 & 1.9 & 2.1 & 2.0 \\
\hline Revenue and grants & 36.4 & 30.9 & 32.0 & & & 39.8 & 33.7 & 33.4 & 32.9 & 31.4 & 31.3 & & 31.3 & 31.3 & \\
\hline of which: grants & 7.4 & 5.2 & 7.2 & & & 15.0 & 8.6 & 7.6 & 6.6 & 5.8 & 5.7 & & 5.7 & 5.7 & \\
\hline Primary (noninterest) expenditure & 35.1 & 32.5 & 35.4 & & & 48.4 & 42.4 & 38.2 & 37.5 & 32.8 & 33.0 & & 33.2 & 33.4 & \\
\hline Automatic debt dynamics & -4.8 & -2.8 & 0.4 & & & 2.2 & -3.9 & -2.8 & -3.1 & -3.4 & -3.3 & & -2.8 & -2.2 & \\
\hline Contribution from interest rate/growth differential & -1.3 & -2.6 & 1.3 & & & 1.3 & -1.9 & -1.7 & -2.0 & -2.2 & -2.2 & & -1.9 & -1.5 & \\
\hline of which: contribution from average real interest rate & -0.4 & -0.8 & -0.3 & & & 0.2 & -0.3 & -0.4 & -0.4 & -0.5 & -0.5 & & -0.5 & -0.4 & \\
\hline of which: contribution from real GDP growth & -0.9 & -1.8 & 1.6 & & & 1.2 & -1.6 & -1.3 & -1.5 & -1.8 & -1.7 & & -1.4 & -1.1 & \\
\hline Contribution from real exchange rate depreciation & -3.6 & -0.2 & -0.9 & & & 0.8 & -2.0 & -1.1 & -1.2 & -1.2 & -1.1 & & & & \\
\hline Other identified debt-creating flows & 0.0 & 0.0 & 0.0 & & & 0.0 & 0.0 & 0.0 & 0.0 & 0.0 & 0.0 & & 0.0 & 0.0 & \\
\hline Privatization receipts (negative) & 0.0 & 0.0 & 0.0 & & & 0.0 & 0.0 & 0.0 & 0.0 & 0.0 & 0.0 & & 0.0 & 0.0 & \\
\hline Recognition of implicit or contingent liabilities & 0.0 & 0.0 & 0.0 & & & 0.0 & 0.0 & 0.0 & 0.0 & 0.0 & 0.0 & & 0.0 & 0.0 & \\
\hline Debt relief (HIPC and other) & 0.0 & 0.0 & 0.0 & & & 0.0 & 0.0 & 0.0 & 0.0 & 0.0 & 0.0 & & 0.0 & 0.0 & \\
\hline Other (specify, e.g. bank recapitalization) & 0.0 & 0.0 & 0.0 & & & 0.0 & 0.0 & 0.0 & 0.0 & 0.0 & 0.0 & & 0.0 & 0.0 & \\
\hline Residual, including asset changes & 3.2 & -5.5 & 6.3 & & & 3.1 & 0.6 & -0.5 & -1.2 & 0.0 & -0.7 & & -0.8 & -0.4 & \\
\hline \multicolumn{16}{|l|}{ Other Sustainability Indicators } \\
\hline PV of public sector debt & $\ldots$ & $\ldots$ & 30.2 & & & 38.6 & 41.0 & 41.9 & 41.8 & 40.5 & 39.0 & & 33.0 & 25.5 & \\
\hline $\mathrm{o} / \mathrm{w}$ foreign-currency denominated & & $\ldots$ & 27.9 & & & 36.7 & 39.4 & 40.4 & 40.5 & 39.4 & 38.1 & & 32.6 & 25.5 & \\
\hline o/w external & $\ldots$ & $\ldots$ & 27.9 & & & 36.7 & 39.4 & 40.4 & 40.5 & 39.4 & 38.1 & & 32.6 & 25.5 & \\
\hline PV of contingent liabilities (not included in public sector debt) & & $\ldots$ & 1.2 & & & 1.1 & 0.9 & 0.7 & 0.6 & 0.5 & 0.4 & & 0.1 & 0.0 & \\
\hline Gross financing need $2 /$ & 0.3 & 2.8 & 4.9 & & & 11.0 & 10.9 & 6.9 & 6.7 & 3.5 & 3.8 & & 3.9 & 3.5 & \\
\hline PV of public sector debt-to-revenue and grants ratio (in percent) & $\ldots$ & & 94.2 & & & 97.1 & 121.8 & 125.5 & 126.8 & 128.8 & 124.7 & & 105.4 & 81.3 & \\
\hline PV of public sector debt-to-revenue ratio (in percent) & $\ldots$ & $\ldots$ & 121.5 & & & 156.0 & 163.5 & 162.2 & 158.7 & 157.8 & 152.5 & & 128.8 & 99.4 & \\
\hline o/w external $3 /$ & & & 112.3 & & & 148.1 & 156.9 & 156.6 & 154.0 & 153.6 & 149.0 & & 127.5 & 99.4 & \\
\hline Debt service-to-revenue and grants ratio (in percent) $4 /$ & 4.7 & 4.1 & 4.9 & & & 5.9 & 6.3 & 6.2 & 6.6 & 6.8 & 6.6 & & 6.3 & 4.4 & \\
\hline Debt service-to-revenue ratio (in percent) $4 /$ & 5.8 & 4.9 & 6.4 & & & 9.5 & 8.5 & 8.0 & 8.2 & 8.4 & 8.1 & & 7.6 & 5.4 & \\
\hline Primary deficit that stabilizes the debt-to-GDP ratio & 1.7 & 8.3 & -6.7 & & & -5.3 & 3.4 & 3.3 & 4.3 & 3.5 & 4.0 & & 3.6 & 2.6 & \\
\hline \multicolumn{16}{|l|}{ Key macroeconomic and fiscal assumptions } \\
\hline Real GDP growth (in percent) & 2.3 & 5.0 & -4.9 & 3.7 & 3.8 & -2.8 & 3.0 & 2.2 & 2.6 & 3.0 & 3.0 & 1.8 & 3.0 & 3.0 & 3.0 \\
\hline Average nominal interest rate on forex debt (in percent) & 2.2 & 0.7 & 1.7 & 1.7 & 2.2 & 1.5 & 1.1 & 1.0 & 1.0 & 1.0 & 1.0 & 1.1 & 0.9 & 0.8 & 0.9 \\
\hline Average real interest rate on domestic debt (in percent) & & & & & & 9.6 & 3.8 & 5.8 & 5.8 & 5.8 & 5.8 & 6.1 & 5.6 & 1.6 & 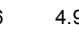 \\
\hline Real exchange rate depreciation (in percent, + indicates depreciation) & -9.2 & -0.6 & -2.8 & -5.2 & 5.6 & 2.1 & & & $\ldots$ & $\ldots$ & $\ldots$ & $\ldots$ & $\ldots$ & & \\
\hline Inflation rate (GDP deflator, in percent) & 7.0 & 4.9 & 9.8 & 3.9 & 4.6 & -0.5 & 6.1 & 4.0 & 4.0 & 4.0 & 3.9 & 3.6 & 3.9 & 3.9 & 3.9 \\
\hline Growth of real primary spending (deflated by GDP deflator, in percent) & 0.2 & 0.0 & 0.0 & 0.0 & 0.1 & 0.3 & -0.1 & -0.1 & 0.0 & -0.1 & 0.0 & 0.0 & 0.0 & 0.0 & 0.0 \\
\hline Grant element of new external borrowing (in percent) & & 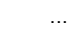 & & & $\ldots$ & 40.9 & 44.9 & 42.3 & 44.8 & 43.7 & 43.1 & 43.3 & 43.1 & 43.1 & \\
\hline
\end{tabular}

Sources: Samoan authorities; and staff estimates and projections.

$1 /$ Includes publicly guaranteed debt.

$2 /$ Gross financing need is defined as the primary deficit plus debt service plus the stock of short-term debt at the end of the last perio

$3 /$ Revenues excluding grants.

sum of interest and amortization of medium and long-term debt.

$5 /$ Historical averages and standard deviations are for the past 10 years. 
Table 1b.Samoa: Sensitivity Analysis for Key Indicators of Public Debt 2010-2030

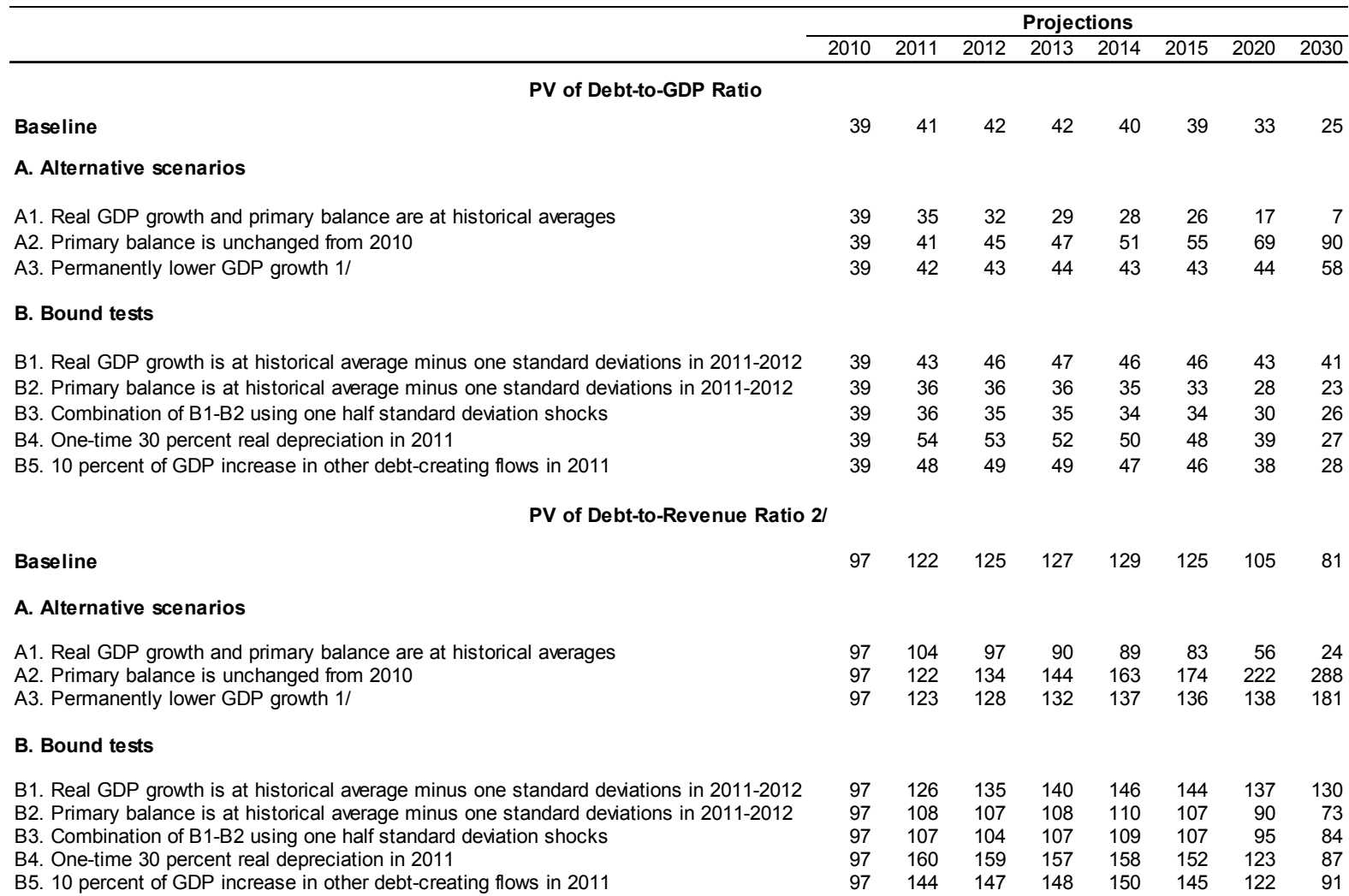

Debt Service-to-Revenue Ratio 2/

\section{Baseline}

\section{A. Alternative scenarios}

A1. Real GDP growth and primary balance are at historical averages

A2. Primary balance is unchanged from 2010

A3. Permanently lower GDP growth $1 /$

$\begin{array}{rrrrrrrr}6 & 6 & 6 & 6 & 6 & 6 & 4 & 1 \\ 6 & 6 & 6 & 7 & 7 & 7 & 8 & 16 \\ 6 & 6 & 6 & 7 & 7 & 7 & 7 & 8\end{array}$

\section{B. Bound tests}

B1. Real GDP growth is at historical average minus one standard deviations in 2011-2012

B2. Primary balance is at historical average minus one standard deviations in 2011-2012

B3. Combination of B1-B2 using one half standard deviation shocks

B4. One-time 30 percent real depreciation in 2011

B5. 10 percent of GDP increase in other debt-creating flows in 2011

$\begin{array}{rrrrrrrr}6 & 6 & 6 & 7 & 7 & 7 & 7 & 7 \\ 6 & 6 & 6 & 6 & 6 & 6 & 5 & 3 \\ 6 & 6 & 6 & 6 & 6 & 6 & 5 & 4 \\ 6 & 7 & 8 & 9 & 10 & 9 & 9 & 8 \\ 6 & 6 & 7 & 7 & 7 & 7 & 8 & 6\end{array}$

Sources: Samoan authorities; and staff estimates and projections.

1/ Assumes that real GDP growth is at baseline minus one standard deviation divided by the square root of the length of the projection period.

2/ Revenues are defined inclusive of grants. 
Table 2a. Samoa: External Debt Sustainability Framework, Baseline Scenario, 2007-2030 1/ (In percent of GDP, unless otherwise indicated)

\begin{tabular}{|c|c|c|c|c|c|c|c|c|c|c|c|c|c|c|c|c|c|c|c|}
\hline & \multicolumn{3}{|c|}{ Actual } & \multirow{2}{*}{$\begin{array}{l}\text { Historical } \\
\text { Average }\end{array}$} & \multirow{2}{*}{$\begin{array}{l}\text { Standard } \\
\text { Deviation }\end{array}$} & \multicolumn{14}{|c|}{ Projections } \\
\hline & 2007 & 2008 & 2009 & & & 2010 & 2011 & 2012 & 2013 & 2014 & 2015 & $\begin{array}{c}2010-2015 \\
\text { Average }\end{array}$ & 2016 & 2017 & 2018 & 2019 & 2020 & 2030 & $\begin{array}{c}2016-2030 \\
\text { Average }\end{array}$ \\
\hline External debt (nominal) 1/ & 37.1 & 30.3 & 38.1 & & & 52.4 & 58.1 & 59.8 & 60.2 & 58.3 & 56.2 & & 54.3 & 52.4 & 50.6 & 49.0 & 47.4 & 37.3 & \\
\hline $\mathrm{o} / \mathrm{w}$ public and publicly guaranteed (PPG) & 37.1 & 30.3 & 38.1 & & & 52.4 & 58.1 & 59.8 & 60.2 & 58.3 & 56.2 & & 54.3 & 52.4 & 50.6 & 49.0 & 47.4 & 37.3 & \\
\hline Change in external debt & -3.0 & -6.8 & 7.8 & & & 14.3 & 5.7 & 1.7 & 0.4 & -1.9 & -2.1 & & -1.9 & -1.9 & -1.7 & -1.7 & -1.6 & -0.5 & \\
\hline Identified net debt-creating flows & -4.7 & 1.9 & -8.2 & & & 6.6 & 8.9 & 4.5 & 3.2 & -1.6 & -2.4 & & -3.1 & -3.4 & -4.5 & -5.2 & -5.7 & -6.6 & \\
\hline Non-interest current account deficit & 15.2 & 5.9 & 1.5 & 7.1 & 4.0 & 19.5 & 19.5 & 15.1 & 13.8 & 8.6 & 8.0 & 14.1 & 7.4 & 7.2 & 6.9 & 6.9 & 6.9 & 6.9 & 7.0 \\
\hline Deficit in balance of goods and services & 28.6 & 20.9 & 21.4 & & & 39.4 & 37.7 & 35.0 & 35.9 & 31.4 & 30.2 & & 29.0 & 28.2 & 26.8 & 26.0 & 25.2 & 18.6 & \\
\hline Exports & 32.7 & 32.4 & 31.3 & & & 29.7 & 31.9 & 33.5 & 34.4 & 35.4 & 36.4 & & 37.3 & 38.3 & 39.1 & 39.8 & 40.7 & 46.6 & \\
\hline Imports & 61.3 & 53.4 & 52.7 & & & 69.1 & 69.6 & 68.5 & 70.3 & 66.8 & 66.5 & & 66.3 & 66.5 & 65.9 & 65.8 & 66.0 & 65.2 & \\
\hline Net current transfers (negative $=$ inflow) & -19.9 & -22.3 & -22.5 & -21.3 & 1.7 & -25.3 & -25.2 & -26.1 & -26.6 & -27.3 & -26.7 & -26.2 & -26.0 & -25.4 & -24.8 & -24.3 & -23.7 & -18.8 & -22.2 \\
\hline $\mathrm{o} / \mathrm{w}$ official & -0.4 & -0.4 & -0.7 & & & -1.2 & -1.0 & -1.0 & -0.9 & -0.8 & -0.8 & & -0.7 & -0.7 & -0.6 & -0.6 & -0.6 & -0.3 & \\
\hline Other current account flows (negative $=$ net inflow) & 6.4 & 7.2 & 2.6 & & & 5.4 & 7.0 & 6.3 & 4.5 & 4.6 & 4.5 & & 4.4 & 4.5 & 4.9 & 5.2 & 5.4 & 7.1 & \\
\hline Net FDI and official capital transfers (negative = inflow) & -15.5 & -5.4 & -7.4 & -8.0 & 3.1 & -14.6 & -9.7 & -10.0 & -9.8 & -9.1 & -9.3 & -10.4 & -9.5 & -9.6 & -10.4 & -11.1 & -11.7 & -12.6 & -11.8 \\
\hline Endogenous debt dynamics 21 & -4.4 & 1.4 & -2.3 & & & 1.7 & -0.9 & -0.6 & -0.9 & -1.1 & -1.1 & & -1.1 & -1.1 & -1.0 & -1.0 & -1.0 & -0.8 & \\
\hline Contribution from nominal interest rate & 0.8 & 0.3 & 0.5 & & & 0.6 & 0.5 & 0.6 & 0.6 & 0.6 & 0.5 & & 0.5 & 0.5 & 0.4 & 0.4 & 0.4 & 0.3 & \\
\hline Contribution from real GDP growth & -0.8 & -1.9 & 1.4 & & & 1.1 & -1.5 & -1.2 & -1.5 & -1.7 & -1.6 & & -1.6 & -1.5 & -1.5 & -1.4 & -1.4 & -1.1 & \\
\hline Contribution from price and exchange rate changes & -4.4 & 3.0 & -4.2 & & & & & & & & & & & & & & & & \\
\hline Residual (3-4) 31 & 1.7 & -8.7 & 16.0 & & & 7.7 & -3.2 & -2.7 & -2.8 & -0.2 & 0.3 & & 1.2 & 1.5 & 2.8 & 3.5 & 4.1 & 6.0 & \\
\hline $\mathrm{o} / \mathrm{w}$ exceptional financing & 0.0 & 0.0 & 0.0 & & & 0.0 & 0.0 & 0.0 & 0.0 & 0.0 & 0.0 & & 0.0 & 0.0 & 0.0 & 0.0 & 0.0 & 0.0 & \\
\hline PV of external debt 4/ & $\ldots$ & $\ldots$ & 27.9 & & & 36.7 & 39.4 & 40.4 & 40.5 & 39.4 & 38.1 & & 37.0 & 35.8 & 34.7 & 33.7 & 32.6 & 25.5 & \\
\hline In percent o & $\ldots$ & $\ldots$ & 89.2 & & & 123.5 & 123.3 & 120.8 & 117.8 & 111.1 & 104.9 & & 99.2 & 93.4 & 88.9 & 84.6 & 80.1 & 54.6 & \\
\hline PV of PPG external debt & $\ldots$ & $\ldots$ & 27.9 & & & 36.7 & 39.4 & 40.4 & 40.5 & 39.4 & 38.1 & & 37.0 & 35.8 & 34.7 & 33.7 & 32.6 & 25.5 & \\
\hline In percent of exports & ... & $\ldots$ & 89.2 & & & 123.5 & 123.3 & 120.8 & 117.8 & 111.1 & 104.9 & & 99.2 & 93.4 & 88.9 & 84.6 & 80.1 & 54.6 & \\
\hline In percent of government revenues & & $\ldots$ & 112.3 & & & 148.1 & 156.9 & 156.6 & 154.0 & 153.6 & 149.0 & & 144.6 & 139.9 & 135.8 & 131.6 & 127.5 & 99.4 & \\
\hline Debt service-to-expor & 5.2 & 3.9 & 5.1 & & & 6.3 & 5.7 & 5.3 & 5.6 & 5.4 & 5.1 & & 4.8 & 5.0 & 4.6 & 4.6 & 4.6 & 3.0 & \\
\hline PPG debt service-to-exports ratio (in percent) & 5.2 & 3.9 & 5.1 & & & 6.3 & 5.7 & 5.3 & 5.6 & 5.4 & 5.1 & & 4.8 & 5.0 & 4.6 & 4.6 & 4.6 & 3.0 & \\
\hline PPG debt service-to-re & 5.8 & 4.9 & 6.4 & & & 7.5 & 7.3 & 6.9 & 7.3 & 7.5 & 7.3 & & 7.0 & 7.5 & 7.0 & 7.1 & 7.2 & 5.4 & \\
\hline Total gross financi & 0.0 & 0.0 & 0.0 & & & 0.0 & 0.1 & 0.0 & 0.0 & 0.0 & 0.0 & & 0.0 & 0.0 & 0.0 & 0.0 & 0.0 & -0.1 & \\
\hline Non-interest current account deficit that stabilizes debt ratio & 18.2 & 12.7 & -6.2 & & & 5.3 & 13.8 & 13.4 & 13.4 & 10.5 & 10.1 & & 9.3 & 9.2 & 8.6 & 8.5 & 8.5 & 7.4 & \\
\hline \multicolumn{20}{|l|}{ Key macroeconomic assumptions } \\
\hline Real GDP growth (in percent) & 2.3 & 5.0 & -4.9 & 3.7 & 3.8 & -2.8 & 3.0 & 2.2 & 2.6 & 3.0 & 3.0 & 1.8 & 3.0 & 3.0 & 3.0 & 3.0 & 3.0 & 3.0 & 3.0 \\
\hline GDP deflator in US dollar terms (ch & 12.3 & -7.6 & 15.9 & 6.6 & 10.6 & -0.5 & 6.1 & 4.0 & 4.0 & 4.0 & 3.9 & 3.6 & 3.9 & 3.9 & 3.9 & 3.9 & 3.9 & 3.9 & 3.9 \\
\hline Effective interest rate (percent) $5 /$ & 2.2 & 0.7 & 1.7 & 1.7 & 2.2 & 1.5 & 1.1 & 1.0 & 1.0 & 1.0 & 1.0 & 1.1 & 0.9 & 0.9 & 0.9 & 0.9 & 0.9 & 0.8 & 0.9 \\
\hline Growth of exports of G\&S (US dollar terms, in pe & 12.8 & -3.8 & 6.2 & 11.3 & 9.8 & -8.2 & 17.5 & 11.3 & 9.6 & 10.4 & 9.8 & 8.4 & 9.8 & 9.9 & 9.1 & 9.1 & 9.4 & 8.4 & 8.8 \\
\hline Growth of imports of G\&S (US dollar terms & 16.4 & -15.6 & 8.7 & 11.8 & 11.6 & 27.0 & 10.0 & 4.6 & 9.6 & 1.8 & 6.6 & 9.9 & 6.7 & 7.3 & 6.1 & 6.8 & 7.3 & 7.0 & 6.9 \\
\hline Grant element of new public sector borrowing (in percent) & & & & $\ldots$ & $\ldots$ & 40.9 & 44.9 & 42.3 & 44.8 & 43.7 & 43.1 & 43.3 & 43.1 & 43.1 & 43.1 & 43.1 & 43.1 & 43.1 & 43.1 \\
\hline Government revenues (excluding grants, in percent of GDP) & 29.1 & 25.7 & 24.8 & & & 24.8 & 25.1 & 25.8 & 26.3 & 25.6 & 25.6 & & 25.6 & 25.6 & 25.6 & 25.6 & 25.6 & 25.6 & 25.6 \\
\hline Aid flows (in Billions of US dollars) 71 & 0.0 & 0.0 & 0.0 & & & 0.1 & 0.1 & 0.1 & 0.1 & 0.1 & 0.1 & & 0.1 & 0.1 & 0.1 & 0.1 & 0.1 & 0.2 & \\
\hline o/w Grants & 0.0 & 0.0 & 0.0 & & & 0.1 & 0.1 & 0.0 & 0.0 & 0.0 & 0.0 & & 0.0 & 0.1 & 0.1 & 0.1 & 0.1 & 0.1 & \\
\hline o/w Concessional loan & 0.00 & 0.00 & 0.00 & & & 0.07 & 0.07 & 0.04 & 0.04 & 0.03 & 0.02 & & 0.03 & 0.03 & 0.03 & 0.03 & 0.03 & 0.06 & \\
\hline Grant-equivalent financing (in percent of GDP) & 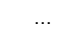 & $\ldots$ & $\ldots$ & & & 20.8 & 13.7 & 10.2 & 9.1 & 7.3 & 7.0 & & 7.0 & 7.0 & 7.0 & 7.0 & 7.0 & 7.0 & 7.0 \\
\hline Grant-equivalent financing (in percent of extemal financing) & & & $\ldots$ & & & 71.2 & 68.5 & 73.6 & 75.0 & 78.8 & 80.1 & & 80.1 & 80.1 & 80.1 & 80.1 & 80.1 & 80.1 & 80.1 \\
\hline \multirow{2}{*}{\multicolumn{20}{|c|}{ Memorandum item }} \\
\hline Nominal GDP (Billions of US dollars) & 0.5 & 0.5 & 0.6 & & & 0.5 & 0.6 & 0.6 & 0.7 & 0.7 & 0.8 & & 0.8 & 0.9 & 0.9 & 1.0 & 1.1 & 2.1 & \\
\hline Nominal dollar GDP growth & 14.9 & -3.0 & 10.2 & & & -3.3 & 9.3 & 6.3 & 6.7 & 7.1 & 7.0 & 5.5 & 7.0 & 7.0 & 7.0 & 7.0 & 7.0 & 7.0 & 7.0 \\
\hline
\end{tabular}

Sources: Samoan authorities; and staff estimates and projections.

1/ Public external debt. Fiscal year ending in June.

2/ Derived as $[r-g-\rho(1+g) /(1+g+\rho+g \rho)$ imes previous period debt ratio, with $r=$ nominal interest rate; $g=$ real GDP growth rate, and $\rho=$ growth rate of GDP deflator in U.S. dollar terms.

$3 /$ Includes exceptional financing (i.e., changes in arrears and debt relief); changes in gross foreign assets; and valuation adjustments. For projections also includes contribution from price and exchange rate changes.

4/ Assumes that PV of private sector debt is equivalent to its face value.

6/ Historical averages and standard deviations are for the past 10 years.

7/ Defined as grants, concessional loans, and debt relief.

CInternational Monetary Fund. Not for Redistribution 
Table 2b. Samoa: Sensitivity Analysis for Key Indicators of Public and Publicly Guaranteed External Debt, 2010-2030

(In percent)

Projections

$\begin{array}{llllll}2010 & 2011 & 2012 & 2013 & 2020 & 2030\end{array}$

PV of Debt-to GDP Ratio

Baseline

\section{A. Alternative Scenarios}

A1. Key variables at their historical averages in 2010-2030 1/

A2. New public sector loans on less favorable terms in 2010-2030 2

\section{B. Bound Tests}

B1. Real GDP growth at historical average minus one standard deviation in 2011-2012

B2. Export value growth at historical average minus one standard deviation in 2011-2012 3/

B3. US dollar GDP deflator at historical average minus one standard deviation in 2011-2012

B4. Net non-debt creating flow $s$ at historical average minus one standard deviation in 2011-2012 4/

B5. Combination of B1-B4 using one-half standard deviation shocks

B6. One-time 30 percent nominal depreciation relative to the baseline in 2011 5/

\section{PV of Debt-to-Exports Ratio}

\section{Baseline}

\section{A. Alternative Scenarios}

A1. Key variables at their historical averages in 2010-2030 1/

A2. New public sector loans on less favorable terms in 2010-2030 2

$37 \quad 39$

37

37

33

43

40

41

33

25

\section{B. Bound Tests}

B1. Real GDP growth at historical average minus one standard deviation in 2011-2012

B2. Export value growth at historical average minus one standard deviation in 2011-2012 3/

B3. US dollar GDP deflator at historical average minus one standard deviation in 2011-2012

B4. Net non-debt creating flow s at historical average minus one standard deviation in 2011-2012 4/

B5. Combination of B1-B4 using one-half standard deviation shocks

B6. One-time 30 percent nominal depreciation relative to the baseline in $20115 /$

\section{PV of Debt-to-Revenue Ratio}

Baseline

\section{A. Alternative Scenarios}

A1. Key variables at their historical averages in 2010-2030 1/

A2. New public sector loans on less favorable terms in 2010-2030 2

148

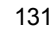

131
171

114

177

99

180

95
169

147

\section{B. Bound Tests}

B1. Real GDP growth at historical average minus one standard deviation in 2011-2012

B2. Export value growth at historical average minus one standard deviation in 2011-2012 3/

B3. US dollar GDP deflator at historical average minus one standard deviation in 2011-2012

B4. Net non-debt creating flow s at historical average minus one standard deviation in 2011-2012 4/

B5. Combination of B1-B4 using one-half standard deviation shocks

B6. One-time 30 percent nominal depreciation relative to the baseline in 2011 5/

162
167
174
181
197
219


Table 2b. Samoa: Sensitivity Analysis for Key Indicators of Public and Publicly Guaranteed External Debt, 2010-2030 (continued) (In percent)

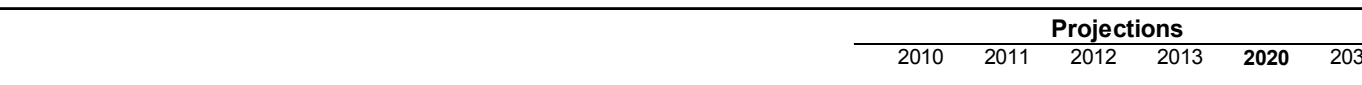

Debt Service-to-Exports Ratio

Baseline

\section{A. Alternative Scenarios}

A1. Key variables at their historical averages in 2010-2030 1/ A2. New public sector loans on less favorable terms in 2010-2030 2

\section{B. Bound Tests}

B1. Real GDP growth at historical average minus one standard deviation in 2011-2012 B2. Export value growth at historical average minus one standard deviation in 2011-2012 3/ B3. US dollar GDP deflator at historical average minus one standard deviation in 2011-2012 B4. Net non-debt creating flows at historical average minus one standard deviation in 2011-2012 4/ B5. Combination of B1-B4 using one-half standard deviation shocks

B6. One-time 30 percent nominal depreciation relative to the baseline in $20115 /$
6

6

\section{Debt Service-to-Revenue Ratio}

\section{Baseline}

\section{A. Alternative Scenarios}

A1. Key variables at their historical averages in 2010-2030 1/ A2. New public sector loans on less favorable terms in 2010-2030 2

\section{B. Bound Tests}

B1. Real GDP growth at historical average minus one standard deviation in 2011-2012 B2. Export value growth at historical average minus one standard deviation in 2011-2012 3/ B3. US dollar GDP deflator at historical average minus one standard deviation in 2011-2012 B4. Net non-debt creating flows at historical average minus one standard deviation in 2011-2012 4/ B5. Combination of B1-B4 using one-half standard deviation shocks

B6. One-time 30 percent nominal depreciation relative to the baseline in 20115 /

Memorandum item:

Grant element assumed on residual financing (i.e., financing required above baseline) 6/

$\begin{array}{llllll}8 & 7 & 6 & 6 & 5 & 4 \\ 8 & 7 & 7 & 8 & 9 & 8\end{array}$

$\begin{array}{rrrrrr}8 & 7 & 7 & 8 & \mathbf{8} & 6 \\ 8 & 7 & 7 & 8 & \mathbf{8} & 6 \\ 8 & 8 & 8 & 9 & \mathbf{9} & 6 \\ 8 & 7 & 7 & 8 & \mathbf{9} & 7 \\ 8 & 8 & 8 & 9 & \mathbf{1 0} & 8 \\ 8 & 10 & 10 & 10 & \mathbf{1 0} & 8 \\ & & & & & \\ 42 & 42 & 42 & 42 & \mathbf{4 2} & 42\end{array}$

Sources: Samoan authorities; and staff estimates and projections.

1/ Variables include real GDP growth, growth of GDP deflator (in U.S. dollar terms), non-interest current account in percent of GDP, and non-debt creating flows. $2 /$ Assumes that the interest rate on new borrowing is by 2 percentage points higher than in the baseline, while grace and maturity periods are the same as in the baseline.

3/ Exports values are assumed to remain permanently at the lower level, but the current account as a share of GDP is assumed to return to its baseline level after the shock (implicitly assuming an offsetting adjustment in import levels).

4/ Includes official and private transfers and FDI.

5/ Depreciation is defined as percentage decline in dollar/local currency rate, such that it never exceeds 100 percent.

6/ Applies to all stress scenarios except for A2 (less favorable financing) in which the terms on all new financing are as specified in footnote 2 .

\section{CInternational Monetary Fund. Not for Redistribution}


Figure 1. Samoa: Indicators of Public and Publicly Guaranteed External Debt Under Alternative Scenarios, 2010-2030 1/
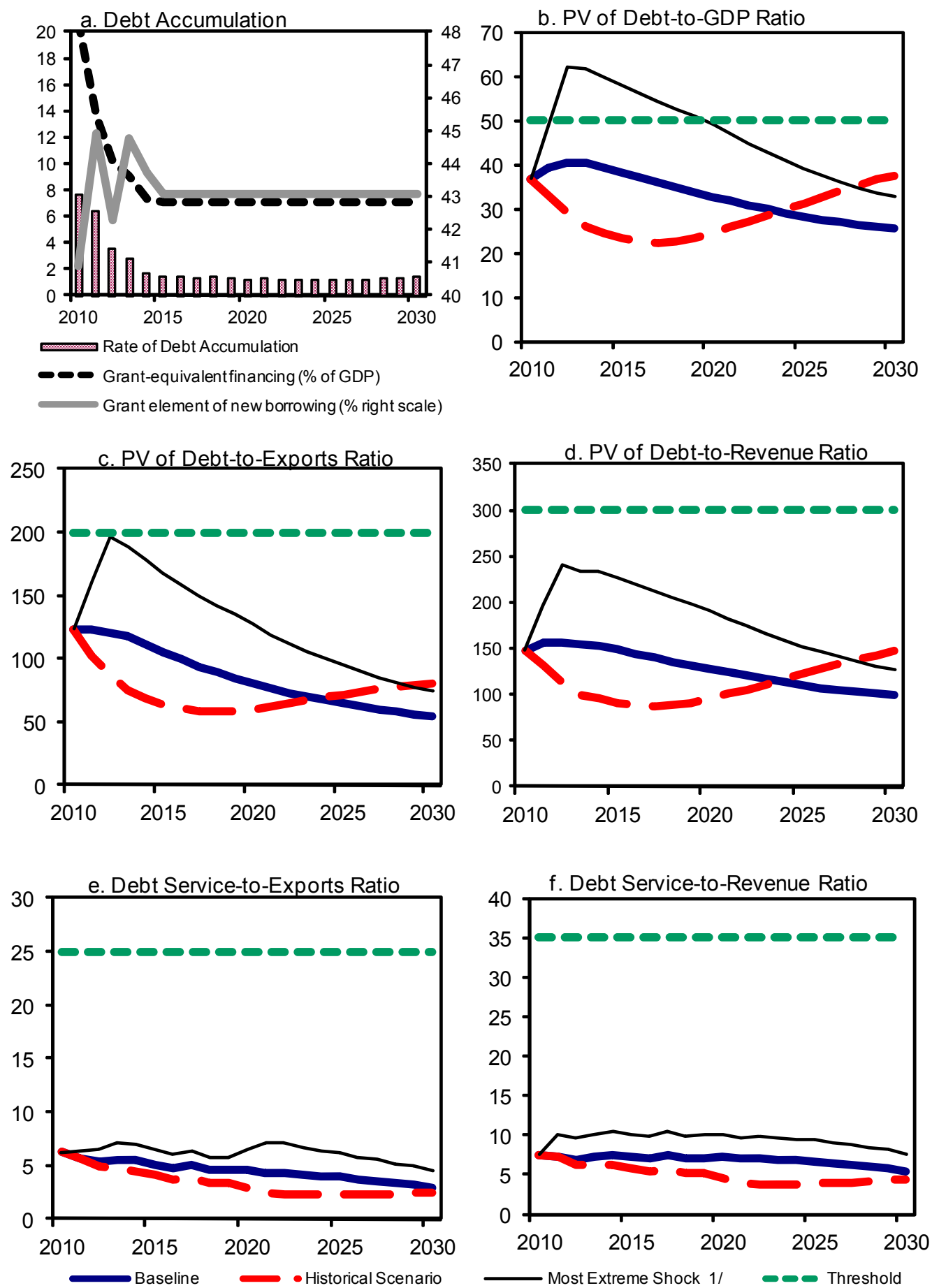

Sources: Samoan authorities; and staff estimates and projections.

$1 /$ The most extreme stress test is the test that yields the highest ratio in 2020. In figures $b$. and d. it corresponds to a one-time depreciation shock (30 percent in real terms); and in all others to a combination shock (GDP grow th and the primary balance fall by 1 standard deviation from their historical average). 
Figure 2. Samoa: Indicators of Public Debt Under Alternative Scenarios, 2010-30 1/
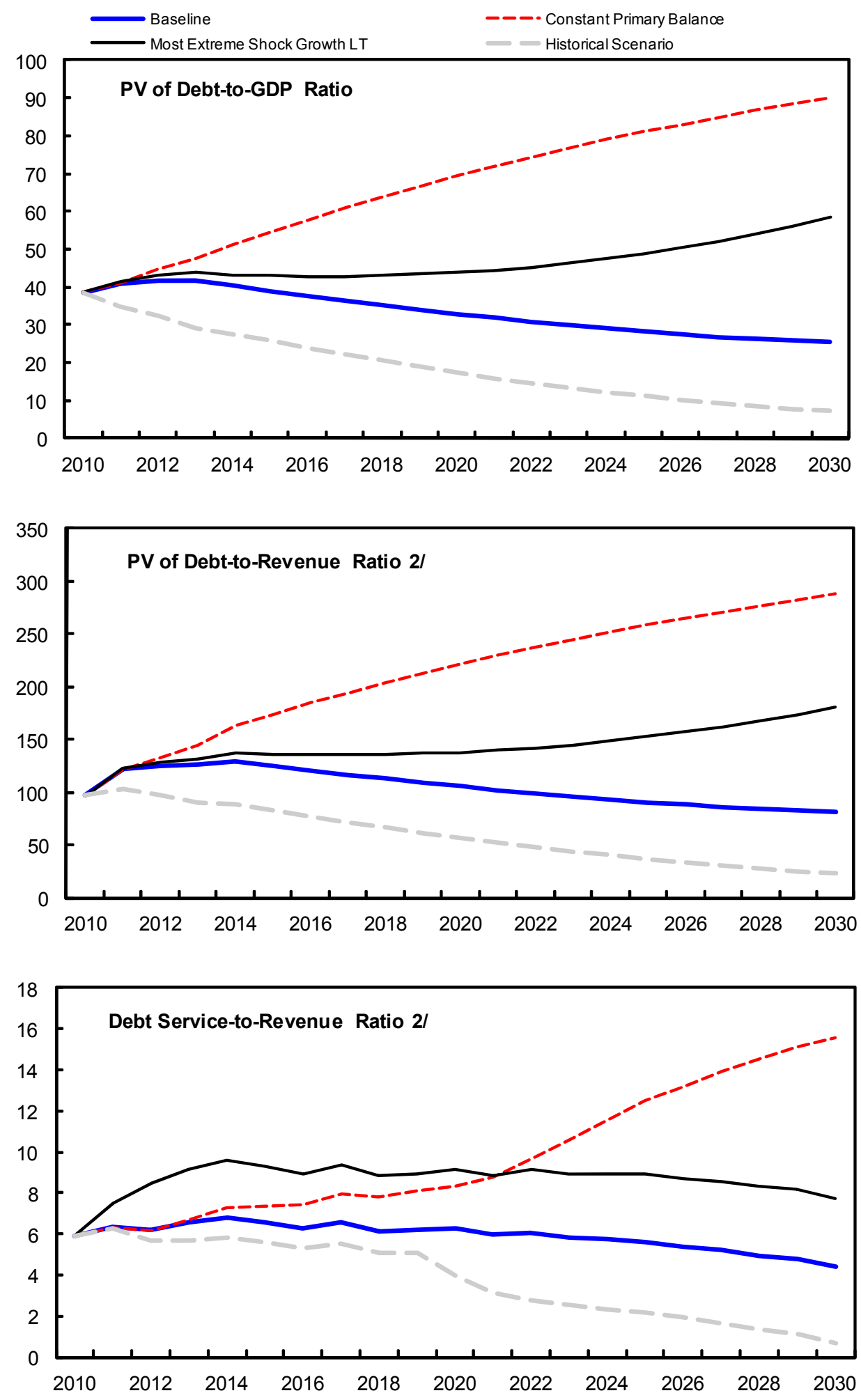

Sources: Samoan authorities; and staff estimates and projections.

$1 /$ The most extreme stress test is the test that yields the highest ratio in 2020.

2/ Revenues are defined inclusive of grants.

\section{CInternational Monetary Fund. Not for Redistribution}


Figure 3. Samoa: Indicators of Public and Publicly Guaranteed External Debt Under Alternative Scenarios, 2010-2030 1/

a. PV of Debt to GDP and Remittances Ratio

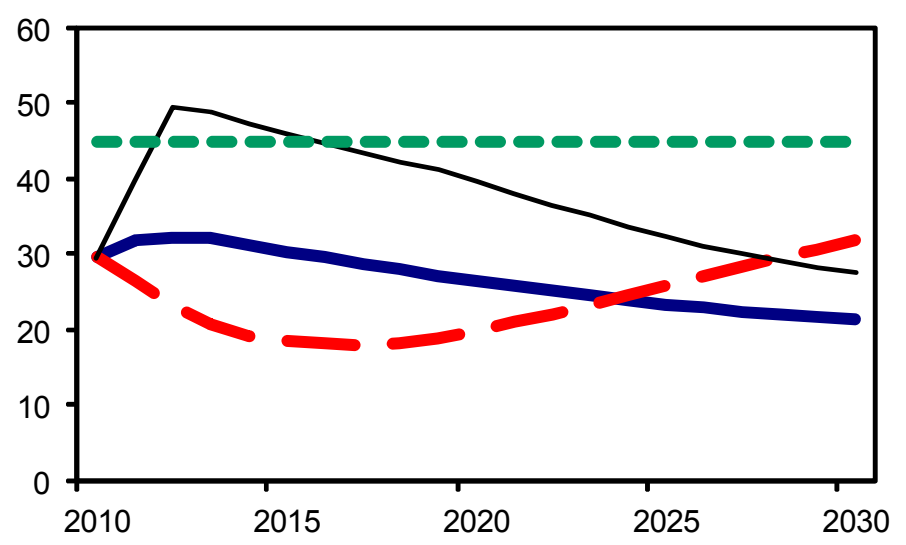

b. PV of Debt to Exports and Remittances Ratio

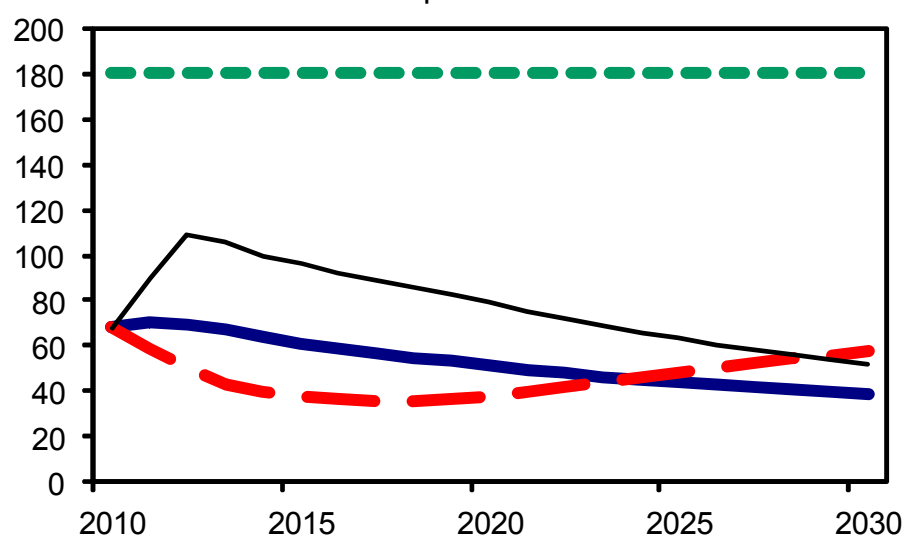

c. Debt Service to Exports and Remittances Ratio

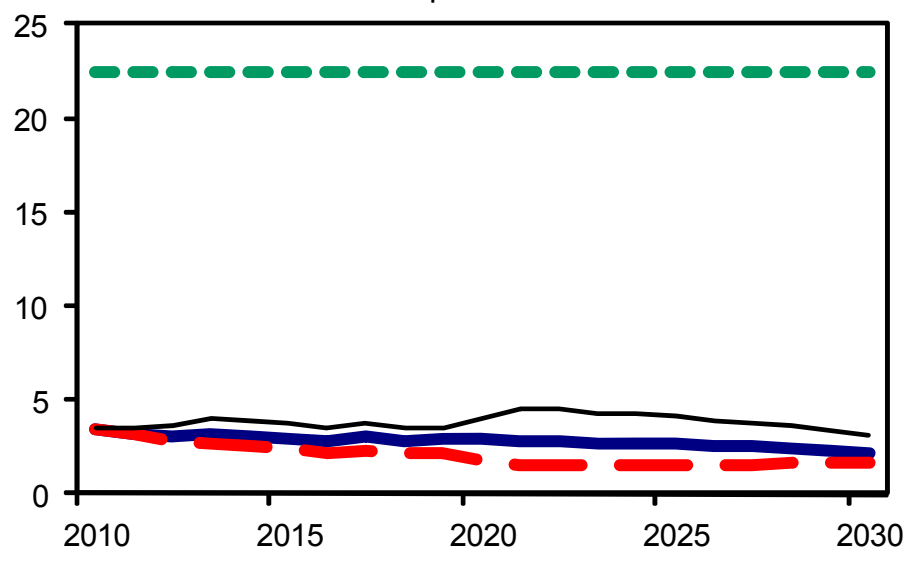

Sources: Samoan authorities; and staff estimates and projections.

1/ The most extreme stress test is the test that yields the highest ratio in 2020. This corresponds to a combination of one-half standard deviation shocks to GDP grow th, non-debt flow s, exports and GDP deflator. 
INTERNATIONAL MONETARY FUND

SAMOA

\section{Article IV Consultation-Informational Annex}

Prepared by the Asia and Pacific Department

(In consultation with other departments)

April 22, 2010

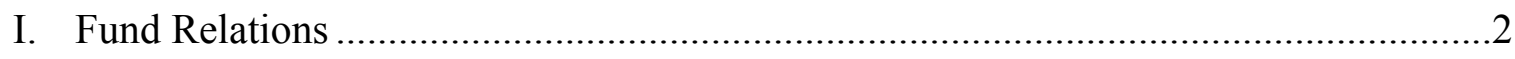

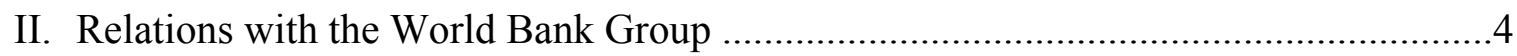

III. Relations with the Asian Development Bank ..........................................................6

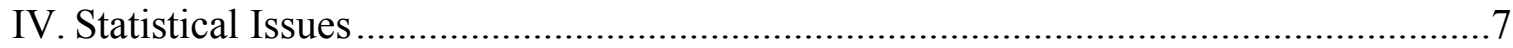




\section{ANNEX I: SAMOA-FUND RELATIONS}

(As of February 28, 2010)

I. Membership Status: Joined: 12/28/1971; Article VIII

II. General Resources Account:

$\underline{\text { SDR Million }}$

\%Quota

Quota

11.60

100.0

Fund holdings of currency

10.92

94.12

Reserve position in Fund

0.69

5.98

III. SDR Department:

$\underline{\text { SDR Million }}$

\%Allocation

Net cumulative allocation

11.09

100.00

Holdings

12.60

113.59

IV. Outstanding Purchases and Loans:

$\underline{\text { SDR Million }}$

\%Quota

ESF RAC Loan

5.80

50.00

V. Latest Financial Arrangements:

\begin{tabular}{|c|c|c|c|c|}
\hline Type & $\begin{array}{l}\text { Approval } \\
\text { Date }\end{array}$ & $\begin{array}{c}\text { Expiration } \\
\text { Date }\end{array}$ & $\begin{array}{c}\text { Amount Approved } \\
\text { ( } \underline{\text { SDR million })}\end{array}$ & $\begin{array}{l}\text { Amount Drawn } \\
\text { (SDR million) }\end{array}$ \\
\hline Stand-by & 07/09/1984 & 07/08/1985 & 3.38 & 3.38 \\
\hline Stand-by & $06 / 27 / 1983$ & $06 / 26 / 1984$ & 3.38 & 3.38 \\
\hline
\end{tabular}

VI. Projected Payments to Fund 1/

(SDR Million; based on existing use of resources and present holdings of SDRs):

\begin{tabular}{lcccc} 
Forthcoming \\
\hline$\underline{2010}$ & $\underline{2011}$ & $\underline{2012}$ & $\underline{2013}$ & $\underline{2014}$
\end{tabular}

Principal

$\begin{array}{llllll}\text { Charges/Interest } & \underline{0.00} & \underline{0.00} & \underline{0.02} & \underline{0.02} & \underline{0.02} \\ \text { Total } & \underline{0.00} & \underline{0.00} & \underline{0.02} & \underline{0.02} & \underline{0.02}\end{array}$

${ }^{1 /}$ When a member has overdue financial obligations outstanding for more than three months, the amount of such arrears will be shown in this section.

\section{Exchange Rate Arrangement:}

The exchange rate of the tala is pegged to a trade and payments weighted basket of currencies formally within a \pm 2 percent band. The basket is a composite of the currencies of Samoa's most important trading partners and countries that are major sources of tourism revenue from abroad - New Zealand, Australia, the United States, and Euro countries. 


\section{Article IV Consultation:}

The 2007 Article IV consultation discussions were held in Apia during March 8-20, 2007. The Executive Board discussed the staff report (IMF Country Report No. 07/185) and concluded the consultation on May 18, 2007.

\section{Technical Assistance:}

The Pacific Financial Technical Assistance Centre (PFTAC) has provided assistance on budgetary management, tax administration, financial sector supervision, and balance of payments statistics. MCM has provided assistance on monetary policy operations, foreign reserves management, banking, and insurance supervision and other central banking issues. STA has provided help with national accounts and government finance statistics, and FAD with tax administration.

\section{Safeguards Assessment}

A first time safeguards assessment of the Central Bank of Samoa is underway. The authorities have committed to undergo a safeguards assessment of the Central Bank of Samoa with respect to the ESF-RAC arrangement approved on 12/7/2009. The Central Bank of Samoa has already authorized its external auditor to hold discussions with Fund staff and give access to the most recent external audit reports.

XI. Resident Representative: None 


\section{ANNEX II: SAMOA-RELATIONS WITH THE WORLD BANK GROUP \\ (As of March 2010)}

Since Samoa became a Bank member in June 1974, 16 IDA credits totaling over \$99.7 million have been committed. The Bank has also executed a range of trust fund financed activities. Bank finance for Samoa has focused on supporting the successful reform efforts since the mid1990s. Investments have helped support critical infrastructure, the finance sector, agricultural production, cyclone reconstruction, and health sector reform.

Samoa has an IDA-15 (FY09-FY11) allocation of \$40 million. Samoa's IDA-15 allocation was more than doubled to respond to the devastating tsunami that occurred on September 29, 2009.

Samoa: IDA Lending Operations (as of March, 2010)

\begin{tabular}{|c|c|c|c|}
\hline & Year of Approval & $\begin{array}{l}\text { Original } \\
\text { Amount }\end{array}$ & $\begin{array}{c}\text { Undisbursed } \\
\text { Balance }\end{array}$ \\
\hline & \multicolumn{3}{|c|}{ (In millions of U.S. dollar equivalent) } \\
\hline \multicolumn{4}{|l|}{ Completed projects (IDA) } \\
\hline First highway & 1975 & 4.4 & 0 \\
\hline Agricultural development & 1979 & 8.0 & 0 \\
\hline Second agricultural development & 1980 & 2.0 & 0 \\
\hline Development Bank & 1985 & 2.0 & 0 \\
\hline Multiproject & 1986 & 2.5 & 0 \\
\hline Afulilo hydroelectric dam (AsDB) & 1987 & 3.0 & 0 \\
\hline Telecommunications (AsDB) & 1989 & 4.6 & 0 \\
\hline Emergency road rehabilitation & 1990 & 14.0 & 0 \\
\hline Afulilo hydroelectric dam supplement (AsDB) & 1993 & 1.0 & 0 \\
\hline Emergency road rehabilitation supplement & 1993 & 5.1 & 0 \\
\hline Infrastructure asset management & 1999 & 14.4 & 0 \\
\hline Health sector management & 2000 & 5.0 & 0 \\
\hline Cyclone emergency reconstruction & 2004 & 4.5 & 0 \\
\hline \multicolumn{4}{|l|}{ Current projects (IDA) } \\
\hline Telecommunications and Postal Reform & 2002 & 4.5 & 2.1 \\
\hline Second Infrastructure Asset Mgmt (+2007 Supplement) & 2003 & 21.1 & 7.6 \\
\hline Health Sector Management & 2008 & 3.0 & 2.8 \\
\hline Total & & 99.1 & 12.5 \\
\hline
\end{tabular}

The Bank's current activities in Samoa are in the following areas:

- Infrastructure Asset Management Phase 2. The objective of this second-phase program (approved December 2003, US\$12.8 million plus additional finance of US\$8 million and significant trust fund support) to be carried out over a period of eight years is to enhance the economic, environmental and social sustainability of transport and coastal infrastructure assets, and to manage these assets, natural resources, and disaster risks through an effective partnership with private sector stakeholders. The success of efforts to build private sector contracting capacity - a central element of the program — was evident in the rapid and 
effective response by the Samoan Government and private sector to tsunami recovery and reconstruction efforts.

- Telecommunications and Postal Sector Reform. This project (approved December 2002, US\$4.5 million) assists Samoa to improve the performance of its telecommunications and postal sectors by increasing competition and private sector participation; strengthening institutional and regulatory capacities; and enhancing the provision of telecommunications and postal services, particularly in rural areas. Effective competition in GSM mobile services, achieved through the project, produced spectacular results. The number of overall customers (GSM and fixed line) exceeds 110,000, which is a ten-fold increase from the beginning of the project.

- Health Sector. Through the Health Sector Management project (approved June 2008, IDA US\$5 million), the Bank is supporting government's reform program aimed at promoting preventative healthcare, and ensuring equitable access to a modern, effective, efficient health service, delivered in close collaboration with the private sector. Implementation is within a sector coordination framework, with Australia especially closely involved. Samoa is broadly on track to meet health sector MDGs.

Three new activities are expected to be presented to the Board for consideration in May 2010:

- DPL: A \$20 million development policy credit to assist the government respond to the global economic downturn and to finance post-tsunami reconstruction costs. This is based on a policy matrix developed by the Government in collaboration with the World Bank, the Asian Development Bank, and other key partners. Policy actions are focused on: (i) addressing post-tsunami reconstruction needs, (ii) targeted support to the most vulnerable, (iii) maintaining overall fiscal discipline, (iv) reducing the cost of doing business and SOE reform, and (v) strengthening consultative processes with stakeholders.

- Transport: A $\$ 10$ million investment to strengthen transport and infrastructure services in tsunami affected areas, which will be implemente din conjunction with the current successful SIAM2 operation.

- Health: Additional financing of $\$ 3$ million to assist in addressing pressures on the health system emerging as a result of the tsunami.

In addition, the Samoan Government has requested support from the Bank to undertake reforms to strengthen the competitiveness of the agricultural sector and to increase opportunities for the private sector to access agricultural supply chains for export and for the tourist market.

IFC has been active in Samoa, particularly in the telecoms sector. IFC has invested US\$18.5 million in Digicel, encouraging this new private operator to enter the liberalized Samoan telecoms market. This has been a crucial element in the successes achieved in improving connectivity in Samoa. IFC investments have encouraged over US\$80 million in total private investment in the telecoms sector, making this the largest single private investment in Samoa.

In support of a significantly scaled up program, the Bank in November 2009 opened a joint liaison office in Samoa, in conjunction with the Asian Development Bank. 


\section{ANNEX III: SAMOA-RELATIONS WITH THE ASIAN DEVELOPMENT BANK ${ }^{1}$}

The Asian Development Bank (AsDB) operations in Samoa started in 1969. Up to the end of 2009, 33 loans totaling US\$159.4 million for 30 projects and technical assistance totaling US\$28.68 million for 87 projects have been provided.

The Country Partnership Strategy (CPS) 2008-12 for Samoa focuses on poverty reduction with three pillars for intervention: (i) removal of infrastructure constraints, (ii) improvement of access and delivery of public services, and (iii) promotion of private sector development. The CPS builds on a coordinated strategy with the other main development partners, and acknowledges lessons from the past, by focusing on sectors where AsDB has strong comparative advantage, particularly power; water, sanitation, and drainage; and private sector development.

A Power Sector Expansion Project was approved in 2007, with Japan Bank for International Cooperation and Government of Australia co-financing, for a total amount of US\$88 million. AsDB's approved ADF lending for this project is US\$26.61 million. Two TA grants were approved in 2009 for a total of US\$1.6 million, comprising a project preparatory TA for improved delivery of water supply, sanitation, and drainage services to residents of Greater Apia and a capacity development TA in support of the improved use of customary land. A US\$1.00 million grant has been provided for immediate tsunami relief in October 2009.

Most recently, in April 2010 the Economic Recovery Support Program (totalling US\$26.8 million) was approved and loan funds from subprogram 1 (US\$16 million) are expected to be disbursed by May 2010 .

\begin{tabular}{|l} 
Samoa: AsDB Loan Approvals and Disbursements, 2003-09 \\
(In millions of U.S. dollars) \\
\begin{tabular}{|l|l|l|l|l|l|l|l|}
\hline & 2003 & 2004 & 2005 & 2006 & 2007 & 2008 & 2009 \\
\hline Loan approvals & 8.0 & 0.0 & 8.1 & 0.0 & 26.6 & 2.8 & 0.0 \\
\hline Loan disbursements & 1.9 & 2.8 & 2.7 & 1.6 & 1.4 & 2.6 & 6.3 \\
\hline Cumulative loan amount available & 120.8 & 121.6 & 128.1 & 122.8 & 150.8 & 152.6 & 146.3 \\
\hline Cumulative disbursements & 97.2 & 100.0 & 102.7 & 104.3 & 105.7 & 108.3 & 114.6 \\
\hline Net loan amount undisbursed & 15.7 & 15.3 & 21.6 & 17.4 & 18.5 & 18.0 & 11.7 \\
\hline
\end{tabular} \\
Balance as of December 2009, cumulative since operations began with Samoa in 1969. \\
\hline
\end{tabular}

\footnotetext{
${ }^{1}$ Prepared by the Asian Development Bank staff.
} 


\section{ANNEX IV. SAMOA: STATISTICAL ISSUES}

Data provision is broadly adequate for surveillance. Core economic and monetary data are updated regularly and published on official websites. However, balance of payments data are limited and subject to frequent revisions while expenditure-based national account data are under development.

Samoa participated in the Pacific Regional General Data Dissemination System (GDDS) Project in November 2003. The metadata is undergoing review prior to web-posting consultations with country authorities. On-going technical assistance missions have been provided by STA and PFTAC to improve national account statistics and financial sector indicators. The standardized report forms (SRFs) for reporting monetary data to the IMF and an integrated monetary database became effective in January 2009.

Table of Common Indicators Required for Surveillance (As of April 7, 2009)

\begin{tabular}{|c|c|c|c|c|c|}
\hline & $\begin{array}{c}\text { Date of } \\
\text { Latest } \\
\text { Observation }\end{array}$ & $\begin{array}{c}\text { Date } \\
\text { Received }\end{array}$ & $\begin{array}{c}\text { Frequency } \\
\text { of } \\
\text { Data }^{4}\end{array}$ & $\begin{array}{c}\text { Frequency } \\
\text { of } \\
\text { Reporting }\end{array}$ & $\begin{array}{c}\text { Frequency } \\
\text { of } \\
\text { Publication }^{4}\end{array}$ \\
\hline Exchange Rates & $04 / 6 / 10$ & $04 / 7 / 09$ & $\mathrm{D}$ & $\mathrm{D}$ & $\mathrm{D}$ \\
\hline Gross International Reserves & $02 / 10$ & $04 / 7 / 09$ & M & M & M \\
\hline Reserve/Base Money & $02 / 10$ & 03/24/09 & M & M & M \\
\hline Broad Money & $02 / 10$ & 03/24/09 & M & M & M \\
\hline Central Bank Balance Sheet & $02 / 10$ & 03/24/09 & M & M & M \\
\hline Consolidated Balance Sheet of the Banking System ${ }^{1}$ & $12 / 09$ & $01 / 10$ & M & M & NA \\
\hline Interest Rates ${ }^{2}$ & $02 / 10$ & 03/24/09 & M & M & M \\
\hline Consumer Price Index & $02 / 10$ & 03/24/09 & M & M & M \\
\hline $\begin{array}{l}\text { Revenue, Expenditure, Balance and Composition of } \\
\text { financing }{ }^{3} \text { - Central Government }\end{array}$ & Q4 2009 & $03 / 10$ & Q & Q & Q \\
\hline Stocks of Central Government Debt & Q3 2009 & $02 / 10$ & Q & Q & NA \\
\hline External Current Account Balance & Q3 2009 & $01 / 10$ & Q & Q & Q \\
\hline Exports and Imports of Goods & $02 / 10$ & 03/24/09 & M & M & M \\
\hline GDP & Q3 2009 & $03 / 10$ & Q & Q & Q \\
\hline Gross External Debt & Q3 2009 & $02 / 10$ & Q & Q & Q \\
\hline
\end{tabular}




\section{INTERNATIONAL MONETARY FUND}

Public Information Notice

EXTERNAL

RELATIONS

DEPARTMENT

Public Information Notice (PIN) No. 10/85

FOR IMMEDIATE RELEASE

July 12,2010

International Monetary Fund

$70019^{\text {th }}$ Street, NW

Washington, D. C. 20431 USA

\section{IMF Executive Board Concludes 2010 Article IV Consultation with Samoa}

On May 17, 2010, the Executive Board of the International Monetary Fund (IMF) concluded the Article IV consultation with Samoa. ${ }^{1}$

\section{Background}

After more than a decade of strong economic performance, the global recession and 2009 tsunami dealt Samoa major setbacks. Real per-capita income growth since the mid-1990s has been significantly higher than for most comparator countries. Prudent fiscal and monetary policies and structural reforms underpinned this performance. However, the global recession hit parts of the economy severely, notably manufacturing. In addition, construction also recorded a significant decline, in part reflecting the unwinding of activity related to the South Pacific Games, while agriculture and fishing suffered from poor harvests. As a result, real GDP fell 5 percent in FY 2008/09, recording the worst slump in two decades.

\footnotetext{
${ }^{1}$ Under Article IV of the IMF's Articles of Agreement, the IMF holds bilateral discussions with members, usually every year. A staff team visits the country, collects economic and financial information, and discusses with officials the country's economic developments and policies. On return to headquarters, the staff prepares a report, which forms the basis for discussion by the Executive Board. At the conclusion of the discussion, the Managing Director, as Chairman of the Board, summarizes the views of Executive Directors, and this summary is transmitted to the country's authorities. An explanation of any qualifiers used in summings up can be found here: http://www.imf.org/external/np/sec/misc/qualifiers.htm.
} 
Nevertheless, Samoa's external position remained comfortable. The current account deficit narrowed in FY 2008/09 (on provisional data) as remittances and tourism receipts, Samoa's main foreign exchange earners, continued to grow. Official reserves remained stable, well above the central bank's target.

The tsunami in September 2009 caused human suffering and damage to physical infrastructure, including tourism, of an unprecedented scale. Beyond the human cost, the physical damage is estimated by the UNDP and the World Bank at US\$60 million (over 10 percent of GDP), but the cost of infrastructure rehabilitation, strengthening social safety nets, investing in disaster protection, resettlement, and lost tourism earnings is expected to be significantly higher.

The authorities responded early in the global recession with monetary and fiscal stimulus. The Central Bank of Samoa (CBS) has lowered policy rates (CBS securities overall rate) by nearly 500 bps since mid 2008 to $1 / 4$ percent. The government also started to increase development spending in 2008 and the pre-tsunami fiscal deficit was budgeted to double to over 10 percent of GDP in FY 2009/10, largely financed by grants and concessional loans.

A massive humanitarian relief effort was mounted within days after the September 2009 tsunami and attention is now shifting toward implementing a recovery framework that focuses on maintaining access to basic health and education services, infrastructure rehabilitation, resettlement and investments in disaster risk reduction. Given the poverty implications of the disaster, the framework is integrated with the Strategy for the Development of Samoa 200812 , Samoa's blue-print for poverty reduction and growth.

A strong initial response from private overseas remittances and donor support, including the Fund's emergency assistance, have helped offset balance of payments pressures so far, with official reserves rising to US $\$ 130$ million at end February 2010 (4 months of prospective import cover).

\section{Executive Board Assessment}

Executive Directors agreed with the thrust of the staff appraisal. They commended the Samoan authorities for their swift response to a series of severe shocks, including the global recession of 2008 and the September 2009 tsunami. They welcomed the adoption of a comprehensive recovery plan, which would help safeguard the social and economic progress achieved by Samoa in recent years. Directors noted, however, that Samoa's prospects for a quick recovery remain challenging and subject to considerable risks, given the scale of the shocks, a still fragile global recovery, and the island's susceptibility to natural disasters. 
Directors commended the authorities for their prudent fiscal policy, which has significantly strengthened the fiscal position in recent years, and welcomed their commitment to return to their deficit target over the medium-term once tsunami-related reconstruction is completed. They noted that stabilizing public debt at a comfortable level would be particularly important for a small open economy, such as Samoa, that is vulnerable to external shocks.

They also noted that the significant fiscal cost of emergency relief and rehabilitation had resulted in sharply higher fiscal deficits in the next few years. Directors supported the prioritization of spending in the supplementary budget, which favors basic social services and areas that are key to revive the economy, and were encouraged by the progress made in securing concessional donor support. To further reduce fiscal risks and minimize remaining tsunami-related financing needs, Directors recommended re-directing some development spending under existing plans to tsunami-related infrastructure rehabilitation. Directors underscored that timely implementation of the government's public financial management reform plan will also be important to ensure efficiency of spending.

Directors supported the authorities' commitment to the exchange-rate basket peg as an effective anchor of sound macroeconomic policies. They noted staff's finding that the exchange rate did not appear out of line with economic fundamentals. Directors stressed that prudent monetary and exchange rate policy will be critical during the reconstruction period and called on the CBS to remain vigilant in detecting early signs of balance of payments pressures. The authorities should stand ready to make exchange-rate adjustments as necessary, and raise policy interest rates to a more neutral level as the domestic recovery gains traction and regional central banks withdraw stimulus.

Directors also encouraged further structural reform to enhance prospects for private sector-led growth, including by building on recent progress in state-owned enterprise reform, and increasing access to and economic use of customary land.

Public Information Notices (PINs) form part of the IMF's efforts to promote transparency of the IMF's views and analysis of economic developments and policies. With the consent of the country (or countries) concerned, PINs are issued after Executive Board discussions of Article IV consultations with member countries, of its surveillance of developments at the regional level, of post-program monitoring, and of ex post assessments of member countries with longer-term program engagements. PINs are also issued after Executive Board discussions of general policy matters, unless otherwise decided by the Executive Board in a particular case. 
Samoa: Selected Economic and Financial Indicators, 2004/05-2008/09 1/

2004/05 2005/06 2006/07 2007/08 2008/09

Est.

Output and inflation

Real GDP growth

Nominal GDP

Change in CPI (end period)

Change in CPI (period average)

Central government budget

Revenue and grants

Expenditure and net lending

Of which: Development

Overall balance

External financing

Domestic financing

Money and credit

Broad money (M2)

Net foreign assets

Net domestic assets

Private sector credit

Balance of payments

Current account balance

(In percent of GDP)

Merchandise exports, f.o.b.

Merchandise imports, c.i.f.

Services (net)

Income (net)

Current transfers

External reserves and debt

Gross official reserves

(In months of next year's imports of GNFS)

External debt (in percent of GDP)

Public external debt-service ratio (in percent)

Exchange rates

Market rate (tala/U.S. dollar, period average)

Market rate (tala/U.S. dollar, end period)

Nominal effective exchange rate $(2000=100) 2 /$

Real effective exchange rate $(2000=100) 2 /$ (12-month percent change)

$\begin{array}{rrrrr}7.0 & 2.2 & 2.3 & 5.0 & -4.9 \\ 11.2 & 8.6 & 9.4 & 10.1 & 4.3 \\ 1.0 & 2.1 & 8.0 & 8.8 & 9.8 \\ 7.8 & 3.2 & 4.5 & 6.2 & 14.4\end{array}$

(In percent of GDP)

$\begin{array}{rrrrr}36.3 & 31.8 & 36.4 & 30.9 & 32.0 \\ 36.1 & 32.3 & 35.8 & 32.7 & 35.9 \\ 13.1 & 7.1 & 9.3 & 6.5 & 11.9 \\ 0.3 & -0.5 & 0.6 & -1.8 & -3.8 \\ 1.4 & 0.5 & -1.1 & 0.8 & 2.9 \\ -1.7 & 0.0 & 0.4 & 1.0 & 0.9\end{array}$

(12-month percent change)

$\begin{array}{rrrrr}15.0 & 13.0 & 8.7 & 12.3 & 7.6 \\ 34.4 & -20.2 & 7.8 & 14.4 & 9.0 \\ -0.7 & 79.8 & -0.5 & 1.3 & 6.7 \\ 6.8 & 28.2 & 11.7 & 6.5 & 5.2\end{array}$

(In millions of U.S. dollars)

$\begin{array}{rrrrr}-39.1 & -50.3 & -83.1 & -31.3 & -11.4 \\ -9.6 & -11.1 & -15.9 & -6.2 & -2.0 \\ 12.8 & 11.0 & 12.2 & 11.2 & 10.2 \\ -168.2 & -204.6 & -241.1 & -204.3 & -227.6 \\ 59.7 & 69.9 & 79.3 & 87.1 & 98.0 \\ -34.1 & -36.2 & -37.5 & -38.0 & -17.4 \\ 90.8 & 109.6 & 103.9 & 112.8 & 125.4 \\ & & & & \\ 84.2 & 64.4 & 80.9 & 87.6 & 96.6 \\ 3.7 & 2.4 & 3.6 & 3.6 & 3.5 \\ 39.5 & 40.1 & 37.1 & 30.3 & 38.1 \\ 9.3 & 9.8 & 5.2 & 3.9 & 5.1 \\ & & & & \\ 2.7 & 2.8 & 2.6 & 2.6 & 2.8 \\ 2.8 & 2.7 & 2.6 & 2.9 & 2.8 \\ 101.6 & 100.7 & 100.5 & 98.1 & 99.3 \\ 120.2 & 120.0 & 123.4 & 129.3 & 139.9 \\ & & & & \\ & & & & \\ 1,124 & 1,221 & 1,336 & 1,472 & 1,536 \\ 407 & 455 & 522 & 507 & 558 \\ 2,276 & 2,537 & 2,902 & 2,802 & 3,078\end{array}$

Sources: Data provided by the Samoan authorities and Fund staff estimates.

1/ Fiscal year beginning July 1.

2/ IMF, Information Notice System (calendar year). For 2009, latest as of June quarter. 


\section{Statement by Hi-Su Lee, Executive Director for Samoa and Benjamin Pereira, Alternate Executive Director \\ May 17, 2010}

\section{Background}

1. Our Samoan authorities wish to express their appreciation to the staff for the cordiality and frankness which characterized these consultations. The consultations provided a timely opportunity for our authorities to take stock of the progress made in recent years under the Strategy for the Development of Samoa (SDS) 2008/092011/12 and in the wake of the 2009 tsunami which has greatly affected this small island nation and led to the granting of the ESF-RAC facility late last year. The authorities considered the exchange of views on key policy issues to be useful in supporting their ongoing efforts to preserve macroeconomic stability and to ensure long term growth. They continue to value the Fund's assessment of Samoa's policies through the Article IV consultation process and given the global risks we currently face, they welcome the next Article IV consultation in 24 months time.

2. Samoa's performance has been supported by prudent economic and financial management and the effective implementation of structural reforms over the past decades resulting in real per capita income in excess of $\$ U S 3,000$ p.a. This achievement was underpinned by political stability and the extensive efforts to foster broad consensus for important reforms.

3. As a small island state, Samoa continues to be vulnerable to risks from its small size and population, geographic remoteness, narrow production base, vulnerability to terms of trade fluctuations and susceptibility to natural disasters. Given these vulnerabilities and risks, Samoa registered its worst slump for two decades - a 4.9 percent fall in GDP over 2008-2009 - as a result of the global crisis, and the poor harvests in agriculture and fishing. The effects of the September 2009 tsunami undercut the prospects of a quick recovery from the global recession and saddled Samoa with massive private and public sector rebuilding costs. Accordingly, our Samoan authorities remain committed to continuing with a framework of prudent macroeconomic policies as well as a progressive structural reform agenda for longerterm sustainable growth.

\section{Recent Economic Developments}

4. The latest real GDP statistics - for the year to December 2009 - showed a contraction of 1.8 percent over the corresponding 2008 period. As set out in the staff report, the medium-term prospects for Samoa remain sound and supported by the services sector based on tourism recovery, the implementation of the tsunami rehabilitation work program, and a brighter global outlook. 
5. Core inflation indicated a decline in prices of 2.7 percent in February 2010 over the same period last year. Staff estimates headline inflation to increase to 3.0 percent in 2010/11 and 4.0 percent thereafter as tsunami rehabilitation efforts intensify and global recovery resumes.

6. These developments are expected to underpin recovery in the external sector, and the official reserve cover is likely to remain at 3.5 months of imports in the medium term. Gross external debt is expected to rise from 52.4 percent of GDP in 2009/10 to 58.3 percent in 2013/14 (38.1 percent in net present value terms). At this level, staff and authorities believe that Samoa's debt level will remain low risk.

\section{Macroeconomic Policy \\ Fiscal Policy}

7. Although our Samoan authorities remain committed to prudent fiscal policy, the substantial fiscal requirements for the four-year tsunami recovery framework and the fiscal stimulus to offset the global crisis derailed the meeting of the usual mediumterm fiscal target. The authorities' main fiscal objective is for the budget deficit to return to the medium term target of less than 3.0 percent as set out under the SDS after the completion of the phased tsunami rehabilitation activities in 2013/14.

8. Our authorities welcome the finding in the Debt Sustainability Analysis that there is low risk of debt distress. The authorities are cautious of the fiscal risks posed by the remaining financing gap if it is not filled in a timely manner, and of the pressures on debt sustainability that would come from meeting the financing gap using loans rather than grants. Amid these risks, the World Bank and the Asian Development Bank are front loading budget support disbursements to negate the possibility of a financing gap. The authorities have a retrospective budget reimbursement arrangement with donors for funding tsunami rehabilitation activities, and this has allowed timely implementation of the planned recovery work. The authorities also have the option to effectively adjust the timing of the implementation of the current public sector investment program consistent with their administrative and implementation capacity.

9. To cover for the remaining budget financing gap, driven by the tsunami rehabilitation program, of 7.0 percent of GDP in total from 2010/11 onwards, the authorities will intensify bilateral efforts to attract new grants from donors including the European Union, Australia, New Zealand and other potential development partners. The authorities also see merit in prompt publication of the staff report to further enhance the prospects of future grants and concessional financing. 
10. The Medium-Term Budget Framework has already been established with the first set of forward estimates for 2009/10 - 2011/12 published. The authorities will reactivate the Macroeconomic Policy Coordination Committee, which comprises of the Ministry of Finance and Central Bank, and is to support the credibility of forward estimates. The Public Finance Management Reform Plan (PFMRP) will also involve the Ministry of Revenue to assess the need of further tax and customs reforms and the PFMRP process and roles and responsibilities of institutions will be clearly articulated.

\section{Monetary and Exchange Rate Policy}

11. Our authorities remain strongly committed to the current pegged exchange rate basket regime, which has served Samoa well in anchoring the nominal economy, resulting in stable inflation and strong policy credibility. Despite the severe shocks from the global recession and tsunami, staff found that the exchange rate is in line with fundamentals with nominal exchange rate remaining stable while the real effective rate markedly appreciated. The authorities' view is that the Central Bank of Samoa's (CBS) discretion to adjust the exchange rate by $+/-2.0$ percent against the currency basket is crucial for avoiding undue fiscal tightening during the reconstruction period. This exchange rate adjustment process is controlled by an internal accountability process to ensure its effective and efficient use. The CBS will closely monitor the process to ensure that the risks to the external position and inflationary pressures are minimized. The CBS also stands ready to withdraw current monetary stimulus and move to a neutral stance as the global recovery gains traction.

12. The Samoan authorities are grateful for the staff's assessment as set out in the Selected Issues paper on the effectiveness of the credit channel and monetary transmission. The low degree of pass-through explains in part the authorities' one-off subsidized loan program to small operators in the tourism sector to aid tsunami recovery. Looking beyond the immediate term, the CBS will carefully consider staff recommendations for financial sector development and strengthening oversight and regulation of financial institutions and the system. The authorities also look forward to future engagement with staff on policy steps that might be taken to support development in the financial sector.

13. The Fund financing under the 2009 ESF-RAC was used to bolster official reserves as remittances fell short of their annual growth trend. Our authorities agree that, consistent with price and exchange rate stability, it would be prudent to maintain the reserve cover in the range of $3.5-4.0$ months of imports in the medium term. 


\section{Structural Reforms}

14. Consistent with the SDS and the strategy to make the private sector the engine of growth, the Samoan authorities have made varying degrees of progress in its structural reform agenda since the last Article IV consultation as follows.

\section{Economic Use of Land}

15. The Samoan authorities together with the Asian Development Bank assistance have delicately progressed the land reform program despite its sensitivities and some public opposition. The main objectives of the land reform are easing the lease of customary land and for the land lease agreements to be able to serve as collateral for borrowing. Public communication about the land reform will be fundamental to gaining community support and its ultimate success.

16. To date, the authorities have changed the land registration system and supported progress on the land reform through a necessary land legislation amendment. The authorities note that staff's practical recommendations in Box 2 are consistent with their proposed strategy on this issue. The confidence of the banks in the process of using lease agreement as financial collateral will be crucial to this development. The introduction of the Strata Titles in 2009 will provide more flexibility in terms of common ownership of a building on leased land with the purpose of attracting foreign investment.

\section{State-Owned Enterprises}

17. The authorities concur with staff that successful SOE reform will require placing SOEs on a fully commercial footing, with independence from political directives, hard budget constraints, exposure to competition, and full accountability. Consistent with good international practices, a Cabinet appointed committee is currently reviewing the feasibility of the Cabinet decision to remove all civil and public servants from SOEs' Boards by 1 July 2010. The review will consider the limited pool of directors available for Board selection and will likely involve a substantial contribution from the Institute of Directors in preparing new directors for their Board roles and responsibilities. Also under preparation is the establishment and the designing of a mechanism for creating unit trusts to assist in diversifying ownership of privatized SOEs when the momentum picks up. The authorities are also committed to enforce the Community Service Obligation (CSO) through improving SOEs' CSO awareness and ensuring effective implementation and enforcement of the CSO. 
18. On privatization efforts, our authorities recognize that progress has been slow but are of the view that the delay has been fitting given the adverse effects of the global crisis on the attainable prices of SOEs for divestment/privatization. To move forward, the privatization of SamoaTel is on the card with proceeds from sale to provide for fiscal space.

\section{Agriculture Development}

19. The efforts in agricultural development have been focusing on activities such as the National Export Strategy in 2009 to promote agricultural-based export commodities and import substitutions, the strategy on fruit and vegetables sub-sector, and research on agricultural processing, in the absence of a holistic and encompassing sector planning framework to underpin all these efforts. Therefore, the proposed formulation of a sector plan which is on the pipeline will provide the framework to encapsulate agricultural policies and strategies critical for resource allocation in this sector. The timely assistance from the World Bank will concentrate on the implementation of policy requirements and the required strategies for revitalizing this key sector and identifying Samoa's comparative advantage.

\section{Economic Statistics}

20. As staff noted, Samoa is the only Pacific island that disseminates monthly and quarterly economic statistics through government website. This was only possible through substantial investments in its statistics officers through continuous training from the Fund Training institutions, provision of technical assistances from the Pacific Financial Technical Assistance Cooperation, and the Secretariat of the Pacific Community. The authorities understand the merit of timely and reliable economic statistics, hence the proposed investment to strengthen the capacity and capability of the Bureau of Statistics, including according high priority to improvements to national accounts and the coverage of BOP data. 